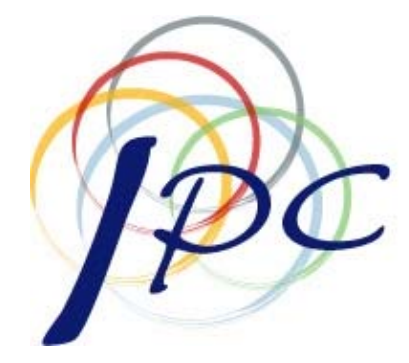

InTERnational Policy Center

Gerald R. Ford School of Public Policy University of Michigan

IPC Working Paper Series Number 7

Exchange Rate Volatility and Regime Change:

Visegrad Comparison

Evzen Kocenda and Juraj Valachy

February 2006 


\title{
Exchange Rate Volatility and Regime Change: Visegrad Comparison
}

\author{
Evžen Kočenda ${ }^{a}$ and Juraj Valachy ${ }^{b}$
}

\begin{abstract}
:
We analyze exchange rate volatility in the Visegrad Four countries in the course of their abandoning tight regimes for more flexible ones. We account for path dependence, asymmetric shocks, movements in interest rates, and allow for generalized error distribution. The overall findings are that volatility path dependence has a limited effect on exchange rate developments and introduction of floating regimes tends to increase exchange rate volatility. During the period of flexible regimes volatility was to a large extent driven by surprises. Degree of persistence in exchange rate volatility is high, differs with respect to currency, but stays at a similar level under the floating regime. Asymmetric news effect tends to decrease volatility under the float. Interest differential contemporaneously impacts exchange rate volatility under either regime, while the interest differential intertemporal effect is not found. Accordingly we draw policy implications.
\end{abstract}

Keywords: exchange rates, exchange rate regimes, volatility, transition, integration, European Union, nonlinearity, interest rate parity

JEL Classification: C14, E42, F31, P59

\footnotetext{
${ }^{a}$ Evžen Kočenda, CERGE-EI (a joint workplace of Charles University and the Academy of Sciences of the Czech Republic), P.O.Box 882, Politických vězňů 7, 11121 Prague, Czech Republic. Tel. (420) 224005149, fax (420) 224227143, e-mail: evzen.kocenda@cerge-ei.cz; WDI at University of Michigan Business School; CEPR, London.

b Juraj Valachy, Institute of Financial Policy, Ministry of Finance, Štefanovičova 5, 81782 Bratislava, Slovakia. Tel. (421) 259582424, fax (421) 259582488, e-mail: jvalachy@mfsr.sk

We would like to thank Jan Babetskii, Balázs Égert, Jan Frait, Jan Hanousek, Jan Kmenta, Ali Kutan, Lucjan Orlowski, and Lucio Vinhas de Souza for helpful comments on earlier drafts of this paper. We also benefited from several presentations. Thanks go to Laura Mentz Straková for her valuable editorial work. While preparing this paper, the authors benefited from grants GACR 402/06/1293 and GDN III - 034. All opinions expressed are those of the authors and have not been endorsed by CERGE-EI, GACR or the GDN. The usual disclaimer applies.
} 


\section{Introduction and motivation}

Exchange rate volatility has been the subject of a considerable amount of research related above all to foreign exchange markets and exchange rate arrangements. ${ }^{1}$ Since the work of Mussa (1986) it has become a stylized fact of international economics that exchange rate volatility under a flexible regime is greater than that under a fixed arrangement. ${ }^{2}$ Much debate has thus centered on the question of how to measure the volatility; over time the approach has shifted from the use of standard deviation towards the use of foreign exchange options and ARCH-type models. ${ }^{3}$ Exchange rate volatility and its measurement have taken on new importance in the context of the transition process in the Central and Eastern European (CEE) countries and their integration into the European Union.

Since the early years of transition, most of the advanced reformers in Central and Eastern Europe have developed independent, autonomous monetary policies. Concurrently, they have departed from fixed exchange rates by applying various "exit strategies" at different times and with different intensity, and have moved towards (a type of) inflation targeting as a policy instrument (Orlowski, 2001). ${ }^{4}$ In addition, economic integration brought increased international trade openness; it has been documented that exchange rate volatility weakens exports, this impact varying across sectors and across CEE countries (Égert and Morales-Zumaquero, 2005), and that a decrease in exchange rate volatility has a positive effect on demand shock convergence (Babetskii, 2005). Further, on the institutional level, exchange rate stability is defined as one of the Maastricht criteria for monetary integration $^{5}$ : as stressed and analyzed by Orlowski (2003), candidate countries for the Economic and Monetary Union (EMU) accession need to demonstrate their capability to manage inflation and exchange rate risk premium as a necessary prerequisite for their successful monetary convergence. In short, diminishing exchange rate risk is suggested as a

\footnotetext{
${ }^{1}$ For classic work see Mussa (1986), Stockman (1988), and Papell (1992) among others. More details are given in Section 2.

${ }^{2}$ Kanas (2005) focuses on the period 1921-2002, which is characterized by different nominal exchange rate regimes and monetary regimes, and finds supporting evidence of the US/UK real exchange rate-real interest differential relation, in terms of volatility regime dependence. The two variables are jointly characterized by high volatility during periods of floating exchange rates, and by low volatility during periods of fixed exchange rates, thereby suggesting that the nominal exchange rate regime is the driving force behind the volatility regime switching.

3 For example, Andersen and Bollerslev (1998) use standard deviation, Figlewski (1997) provides an overview of estimating volatility from option prices, and Glosten, Jagannathan, and Runkle (1993) use ARCH-type proxy of exchange rate volatility.

${ }^{4}$ All this happened relatively swiftly, often during turbulent economic developments and conflicting monetary policies, and undoubtedly affected exchange rate volatility.
} 
key criterion for evaluating currency stability and thus effectiveness of monetary convergence to the euro (Orlowski, 2004).

In this paper we analyze exchange rate volatility in the Visegrad Four countries in the course of their abandoning tight regimes in favor of more flexible ones. ${ }^{6}$ In analyzing exchange rate volatility we account for path dependence, asymmetric shocks, and movements in interest rates. We find that (1) volatility path dependence has a limited effect on exchange rate developments, (2) introduction of floating regimes tends to increase exchange rate volatility, a finding that is broadly in line with the above stylized fact, (3) during the period of flexible regimes volatility was to a large extent driven by surprises, (4) degree of persistence in exchange rate volatility differs with respect to currency but stays at a similar level under the floating regime, (5) asymmetric news effect tends to decrease volatility under the float, and (6) interest rate influences exchange rate volatility in less than obvious ways: under both regimes the contemporaneous effect of interest differential impacts exchange rate volatility, while the interest differential intertemporal effect cannot be assessed due to insignificant coefficients. In our approach we aim to contribute to the empirical as well as methodological debate on exchange rate volatility with an accent on the comparative context of the selected new member states in the process of European integration.

The rest of the paper is organized as follows. Section 2 gives an account of exchange rate developments as well as their arrangements in the Visegrad Four countries. Section 3 discusses exchange rate volatility and sources of this volatility, which are specific to the process of transition. Section 4 describes the methodology to measure volatility while Section 5 gives details about the data and changes in exchange rate regime. In Section 6 we present our results. We conclude with comments and policy implications.

\section{Exchange rates and their arrangements in Central Europe}

\footnotetext{
5 The Maastricht criteria require that the country's currency should have participated without stress in the Exchange Rate Mechanism (ERM) for at least two years prior to being allowed to adopt the euro.

${ }^{6}$ Visegrad Four members are the Czech Republic, Hungary, Poland, and Slovakia. As early as December 1991, the former Czechoslovakia, Poland and Hungary signed the "European Agreement" with the European Union. These countries have striven to establish a workable framework for international trade and cooperation in order to facilitate the transition process. Their effort was institutionalized in March 1993 in the form of the Central European Free Trade Agreement (CEFTA); apart from the Visegrad Four, the agreement was later signed by Slovenia, Bulgaria and Romania. On a broader scale the four countries established a framework for political cooperation by signing the Visegrad agreement. In 1995-6 these countries applied for EU membership and in 2004 became its members.
} 
In Central Europe the institutional design of exchange rate regimes has varied across countries since the beginning of transition. ${ }^{7}$ Yet even though the regimes adopted were quite heterogeneous, we can still observe certain evolutionary similarities; but in no respect do we claim the Visegrad Four to be a homogenous group. The Czech Republic, Hungary, Poland, and Slovakia all adopted fixed exchange rates at the beginning of transition. The Czech and Slovak Republics, which until January 1, 1993 formed a federation and which shared a uniform exchange rate policy, fixed their currencies to a currency basket. At the beginning of transition this basket consisted of five different currencies, and later on of the US dollar and Deutsch mark. The weights of each currency in the basket were determined by the importance of that particular currency to the foreign trade of the country. The width of the band was set at $\pm 0.5 \%$ from central parity. After their separation in 1993, Slovakia changed its band to $\pm 7 \%$ and later the Czech Republic changed it to $\pm 7.5 \%$. Central banks were obliged to intervene in the currency market to sustain the basket peg.

A similar institutional arrangement evolved in Poland and Hungary. The only difference is that these two countries adopted a pre-announced crawling peg to the basket of currencies. ${ }^{8}$ The central parity was not constant, as it was in the case of the Czech Republic or Slovakia, but was changed each month; the periodic devaluations were announced ahead of time. In some cases the width of the band was changed during the period as well. The intricacy of such institutional design is clear from Table 1, which displays in extensive detail all the adjustments that the central banks of the four CEE countries adopted in exchange rate management. The abundance of these adjustments is apparent in the cases of Poland and Hungary. In this context Orlowski (2000a) investigated how various approaches to monetary policy in Poland, Hungary and the Czech Republic influenced the trend and the stability of (real) exchange rates during 1995-1999, and casts doubt on the effectiveness of crawling devaluations.

After the late spring turmoil in financial markets, in May 1997 the Czech Republic was the first Central European country to adopt a floating exchange rate regime. In October 1998, the National Bank of Slovakia followed suit. Later, Poland (in 2000) and Hungary

\footnotetext{
${ }^{7}$ See Bofinger and Wollmershäuser (2001) for a comprehensive overview. Égert (2003) provides a critical survey of the literature on equilibrium exchange rates in the CEE accession countries. The scope of the paper covers the behavior of exchange rates under various regimes as well.

${ }^{8}$ Szapary and Jakab (1998) review Hungary's experience with the pre-announced crawling band exchange rate system during 1995-97. Kemme and Teng (2000) provide a comprehensive analysis of the exchange rate policies in Poland and their effect on export growth.
} 
("quasi" in 2001) also left the fixed regime to adopt a floating regime. We therefore see a general tendency to move from a tight exchange regime to a looser one (Kočenda, 2002; Bofinger and Wollmershäuser, 2001). Yet when these exits from rigid exchange regimes are compared, the movements of Poland and Hungary towards relaxed regimes seem rather "orderly" in contrast with the "disorderly" exits in the Czech Republic and Slovakia. Detragiache, Mody and Okada (2005) claim that "disorderly" exit strategies take place when there are problems with real appreciation, falling reserves, a deteriorating fiscal position, and financial outflows (due to low interest rate differential); "orderly" exits happen when the above macroeconomic problem are absent. ${ }^{9}$ The "disorderly" exits of the Czech and Slovak Republics can thus be explained, at least in good part, by the financial crisis and pre-election turmoil, respectively.

Apart from a shift toward looser exchange rate regimes, the Visegrad Four countries share another similarity, that inflation targeting was adopted, albeit in various forms. The widely implemented form of direct inflation targeting (DIT) as defined, among others, by Svensson (1999) and Orlowski (2000b), "is a policy framework that is based on a preannounced inflation target, on transparent strategies and tactics leading to its accomplishment, and on the policy implementation responding to periodic deviations between inflation forecasts and the inflation target" (see Orlowski, 2001 for a comprehensive account).

All four countries formally applied for EU membership in 1995-6 and underwent a lengthy and thorough screening process. On May 1, 2004 they joined the EU, which means that at some point they will become part of the EMU (or Euro zone) since no opt-out clause was permitted for ten of the recently admitted countries. Although EU membership alone does not mean immediate participation in the Euro zone, membership nevertheless increases pressure on the new member countries to improve their institutions and maintain stable economic environments, and hence should foster euro-conversion-oriented development of their exchange rates. ${ }^{10}$ The operations and timing of euro conversion is an intricate task; in this respect Slovakia is a forerunner as it entered the ERM II regime on November 27, 2005.

\footnotetext{
${ }^{9}$ Kočenda (2005) documents the existence of several key problems inherent to "disorderly" exits in the Czech Republic and Slovakia prior to relaxation of exchange rate regimes.

10 A looser exchange regime with the Euro as a reference currency should be considered the pursuit of a credible peg for a domestic currency with respect to the Euro that allows for necessary responses to the market. Indeed, if a currency fluctuates within a $\pm 15 \%$ band with respect to the Euro, then it implicitly follows the ERM II condition even if the country does not participate formally.
} 


\section{Exchange rate volatility: transition stages and sources}

\subsection{Classic empirics}

Exchange rate volatility in the context of nominal exchange rate regime neutrality in equilibrium models was initially investigated by Mussa (1986), who derived a clear conclusion that has since become a stylized fact in international monetary economics: the variability of real exchange rate is greater under a flexible nominal exchange rate regime than under a fixed arrangement. Based on his analysis, Mussa concluded that the choice of exchange regime has real effects and contradicts those monetary models that assume nominal exchange rate regime neutrality. Real effect is attributed to sluggishness in prices because, while variance of nominal exchange rate increases substantially under the flexible regime, the variance of relative national price levels changes only a little.

Stockman (1988) endorsed Mussa's findings, though he suggested a different explanation. Instead of "sluggish prices", Stockman designed an intertemporal equilibrium model and within this framework argued that real disturbances to supplies and demands for goods were the factors that alter the real exchange rate. ${ }^{11}$ Modification of his model to accommodate flexible prices yields the same result of different variability in exchange rate when changing the regime to greater flexibility. Empirical testing of Stockman's (1988) theory was completed by Papell (1992) on data from the EMS. He argues that it matters how exchange rate variability is defined, and his findings show that if variability is defined as the standard deviation of first differences (as in Mussa, 1986), then change to a flexible regime has a substantial downward effect on real exchange rate variability. However, if the standard deviation of linearly detrended data is used as a volatility measure, then change in regime has no effect on real exchange rate volatility.

Orlowski (2001) proposes a sequence of steps towards monetary convergence to the Euro zone based on autonomous monetary policy rather than on an early application of the euro-peg, and warns against a premature peg to the euro, which may instigate real currency appreciation, large capital inflows, and their costly sterilization.

${ }^{11}$ Under a flexible nominal exchange rate regime a disturbance that depreciates the real exchange rate would be followed by depreciation of the nominal exchange rate. Under a fixed regime, though, a central bank must intervene to support its currency. Such an intervention would cause a change in nominal money and prices coupled with a loss of international reserves. History shows that countries try to prevent the outflow of reserves and possible balance-of-payment crises by imposing various trade restrictions and exchange and capital controls. Stockman (1988) argues that expectations of such policies, adopted in the case of falling reserves, would, with some intertemporal substitution, tend to increase current relative prices through an increase in expected prices, and thus tend to stabilize the real exchange rate. 


\subsection{Effects of transition process and sources of volatility}

Without a doubt, progress in the transition process has to be taken into account when analyzing exchange rate volatility and its sources. In the early stages of transition, the Visegrad Four countries experienced nearly everything that could be characterized as turbulent times and that would tend to increase exchange rate risk: monetary separation (Czech and Slovak Republics), banking crises, financial crises, and political crises. We present several of the most important sources of volatility specific to the Visegrad Four countries in order to provide a brief outline of the systemic and institutional foundations of exchange rate risk. In Section 6 with empirical results we then further elaborate on the extent to which progress in transition has been reflected in our findings.

Quite naturally, volatility has stemmed from the exchange rate arrangements and their modifications as described in detail in Section 2. Even so, differences in exchange rate regimes are not an exclusive source of this volatility, as many other factors exist. Specifically, it is important to recognize that exchange rate risk has been rising in the Visegrad Four countries and that a major underlying reason for this is their questionable outlook for fiscal discipline. These countries are also susceptible to the contagion effects of international financial crises, which tend to increase exchange rate volatility (Orlowski, 2003). Moreover, prior to 2004 the Visegrad Four countries were EU candidates and thus subject to the same pressure on fiscal discipline as they are now, being full members and effectively having entered the path towards monetary integration.

Above all, the impact of the overall monetary policy framework on exchange rate volatility plays an important role. After giving up currency pegs, the Visegrad Four countries adopted policies based on direct inflation targeting (DIT) and gave up an exchange rate stability target by focusing more or less exclusively on inflation targets. Nominal exchange rates are likely to exhibit increasing volatility for at least two reasons. First, regime switching from currency pegs to flexible exchange rates, and as a result of adopting DIT policies that, at least in the case of Poland and to a lesser degree in the Czech Republic, has been accompanied by a benign neglect of exchange rate stability (Orlowski, 2005). Second, during those periods of faster money growth, the pressure on domestic inflation had been rising and contributed to exchange rate volatility as well; Hungary and Poland serve as examples. Without a doubt, a converging economy ought to give priority to the objective of lowering inflation, before placing emphasis on exchange rate stability. This is so because price stability or low inflation is a prerequisite for exchange rate stability, not 
the other way around, as is underscored by the causal effects described in the empirical literature (Orlowski, 2004).

Another source of exchange rate volatility is increasing openness of an economy. ${ }^{12}$ In this respect, trade integration in the Visegrad Four countries is of particular importance. Shortly after the start of the transition process these countries re-directed their foreign trade from the former Soviet bloc towards the EU. Over the years, foreign trade turnover has increased dramatically such that now the ratio of foreign trade turnover to GDP has reached values of around $80 \%$ for Poland to almost $150 \%$ for Slovakia. A reverse link is documented by Égert and Morales-Zumaquero (2005), who analyzed the direct impact of exchange rate volatility on the export performance of ten Central and Eastern European transition economies as well as its indirect impact via changes in exchange rate regimes. Their results suggest that the size and direction of the impact of foreign exchange volatility and of regime changes on exports is negative, varies considerably across sectors and countries, and may be connected to specific periods. In the context of our analysis a high degree of openness is common for all countries in question and, therefore, should contribute to the evolution of volatility of exchange rates in a similar way.

Less clear-cut are those impacts of the transition process that materialize through institutional procedures connected with exchange rate management in a broad sense. Institutional setup is often related to exchange rate risk only indirectly since it reaches beyond an exchange rate arrangement. It involves, among other things, the degree of credibility, the independence of the monetary authority, the existence of targeting mechanisms (inflation, monetary aggregates), and, for the Visegrad Four countries, the process of EU accession, and eventually ERM II and Euro zone membership, with the same sort of expectation effects as observed in the past ERMII-to-Euro zone changeover. The effects of these factors on exchange rates are covered in great detail in Vinhas de Souza (2002). He finds that, for a sample of accession countries, a credible, independent central bank with a floating exchange rate and a targeting mechanism mimics the nominal variability (including exchange rate) properties of a truly fixed exchange rate regime. This

\footnotetext{
${ }^{12} \mathrm{Hau}$ (2002) analyzed the link between openness of an economy and real exchange rate movements in 48 countries and found that trade integration and real exchange rate volatility were structurally linked and that there is a negative correlation between them.
} 
result supports the hypothesis that the volatility of exchange rate is also affected by other institutional factors, not only by the exchange rate regime. ${ }^{13}$

More specific sources of exchange rate volatility and their developments are also observed with respect to tighter versus looser exchange regimes. During the prevailing period when versions of the currency basket peg were used among the Visegrad Four countries, their banking sector was less developed than that of European market economies. As privatization of large state owned banks progressed, as did expansion of new commercial banks from abroad, the degree of competitiveness in the banking sector started to increase. ${ }^{14}$ Although we cannot seamlessly connect the switch of exchange regimes to banking sector improvements, we nevertheless see that during the period of the float the financial system became more developed and less susceptible. That is, it became better able to accommodate a wide range of shocks and better fit to cope with volatility at the same time. Commercial banks, too, after being fully privatized, started to engage more heavily in transactions with foreign exchange; the volumes traded surpassed several times those from earlier stages of transition.

A further source of volatility relates to the countries' balance of payments. Early in transition (that is, under the basket peg regimes) the Visegrad Four began to experience increases in their current account deficits. By using adjustable versions of basket pegs, Poland and Hungary avoided large real exchange rate appreciation; the Czech and Slovak Republics, on the other hand, experienced real appreciation of their currencies, which made managing their current accounts harder but which made it easier for current account volatility to spill over to exchange rate volatility. In the Czech Republic, the mounting current account deficit along with financial crisis increased exchange volatility considerably and had a direct impact on the stance of the central bank towards exchange rate management. All four countries began to liberalize their capital accounts as part of their macroeconomic stabilization packages, but full scale liberalization became a reality only several years later. Such liberalization increased capital account volatility. The deteriorating risk structure of capital inflows towards short-term money further increased the capital

\footnotetext{
${ }^{13}$ We would like to thank Lucio Vinhas de Souza for pointing out this issue. But as we mentioned earlier on the credibility issue, we chose those CEE countries whose institutional setups evolved similarly over the last 10 years. This entails not only a common change from fixed to floating exchange rate regime, but also a similar (or same) quality of monetary authorities, transition experience, timing of EU accession process, EU entry, and expected date of Euro zone membership.

${ }^{14}$ This was documented for example by continuously decreasing interest rate spreads (Kočenda, 2001; Kutan and Yigit, 2004).
} 
account volatility that naturally spilled over to exchange rates. Calmer times came with increased proportions of foreign direct investments, which improved the risk structure of the capital account and lowered its volatility. During the later stages of transition, and under the float regimes, capital account volatility figured less significantly in exchange volatility. For the prospective Euro zone entrants, it is imperative to devise a robust monetary policy framework that will shield their economies from the disruptive effects of capital account volatility by discouraging any presumption of implicit exchange rate guarantees (Schadler, 2004).

\section{Methodology}

\subsection{Theoretical framework to measure volatility}

Many earlier empirical studies based their results on reporting standard deviation as a proxy for exchange rate volatility (see Hallett and Anthony, 1997; Andersen and Bollerslev, 1998; Jorion, 1995; Scott and Tucker, 1989 among others). We believe that such an approach is overly simplistic from both a methodological as well as a theoretical perspective. Using standard deviation as a proxy for the volatility of exchange rates assumes constant average daily returns - yet such an assumption is directly violated under the interest rate parity condition, which is one of the workhorses employed in the analysis of exchange rates. Simply speaking, by using standard deviation as an exchange rate volatility proxy one can detect spurious volatility, which is caused by movements in exchange rates that are generated via interest rate differential. Thus, neglecting movements in interest rates can result in less reliable results.

For that reason we approach the volatility issue in the spirit of the excess volatility debate, i.e. we address whether and to what extent the volatility of exchange rates exceeds the volatility of underlying fundamentals (interest rates in our case). ${ }^{15}$ To approximate an otherwise unobservable volatility we follow one of the approaches suggested by Andersen, Bollerslev, Diebold and Labys (2001). ${ }^{16}$ We aim to fit a parametric econometric model of the ARCH-type (due to Engle, 1982) augmented by appropriate parameters to account for

\footnotetext{
${ }^{15}$ We thank an anonymous referee for this pointing this out.

${ }^{16}$ Andersen, Bollerslev, Diebold and Labys (2001) list three ways to approximate an otherwise unobservable volatility: by (a) fitting parametric econometric models such as generalized autoregressive conditional heteroskedasticity (GARCH); b) calculating direct indicators of volatility such as ex post squared or absolute returns; or (c) calculating volatility implied by option prices. In addition, the authors propose a new volatility measure which they call "realized volatility". It is computed by summing intraday squared returns, and by this definition it is limited to data with intraday frequency.
} 
the effect of interest rate differential on the volatility of exchange rates. To augment our ARCH-type model, which is specified in the next section, we build on the concept of uncovered interest rate parity (UIP). This approach conveniently connects exchange rate and interest rate movements and allows us also to distinguish the effect of interest rates on exchange rate volatility.

From the methodological point of view the use of UIP for exchange rate modeling in the transition context is not uncommon. It stems from Svensson's (2000) modeling strategy for a small open economy and was utilized in the transition context by Golinelli and Rovelli (2002) to analyze monetary policy rules. Such an approach makes sense since, on a practical level, the Visegrad Four countries early in their transition swiftly liberalized their capital accounts and further eased remaining barriers to financial transactions. Consequently, over time, there has been an increasing extent of capital mobility, whose relatively high degree has created a working ground for the UIP, together with the fact that political risk has been decreasing in these countries as well. ${ }^{17}$

Empirical support for UIP among the Visegrad Four countries is evidenced by Golinelli and Rovelli (2005), who adopted the UIP hypothesis for estimating exchange rates in order to account for the process of disinflation in the Czech Republic, Hungary and Poland. They show that the current exchange rate depends on the current interest rate differential and on the expected future exchange rate, augmented by a risk premium. In addition, Chinn (2006) documents reasonable support for UIP in the Czech Republic and Hungary, as well as in other emerging markets. Further empirical support is given by Orlowski (2004), who proposes a model linking exchange rate volatility to differentials across the Euro zone in both inflation (target variable) and interest rate (instrument variable). Through a VAR framework he shows that an increase in domestic interest rates relative to German rates contributes to currency appreciation in the case of the Czech Republic and Hungary, while the results for Poland are inconclusive. Thus, changes in the value of the Polish currency relative to the euro show a considerably weaker response to interest rate differentials than the relative changes in the currencies of the two remaining countries (Czech Republic and Hungary). ${ }^{18}$

\footnotetext{
${ }^{17}$ Chinn (2006) puts forward capital account controls and political risk as two main obstacles precluding the UIP from holding in emerging markets.

${ }^{18}$ This is not a surprise, since the NBP remains fervently committed to a fully flexible exchange rate system, while the CNB follows a managed float strategy and the NBH has applied an ERM II shadowing regime since October 2001 (Orlowski, 2004).
} 
The conventional notion of interest rate parity can be expressed as

$$
s_{t+1}-s_{t}=i_{t}-i_{t}^{*}
$$

where $s_{t}$ denotes the natural logarithm of an exchange rate at time $t ; i_{t}$ and $i_{t}{ }^{*}$ are the domestic and foreign interest rates of equal maturity. For the UIP, $s_{t+1}$ would mean an expected exchange rate one period ahead, while for covered interest rate parity, $s_{t+1}$ would mean a forward rate for one period ahead but known at time $t$. Thus, equation (1) is a usual expression that an intertemporal change in exchange rate, under this theoretical condition, equals the interest rate differential. ${ }^{19}$

Under the UIP condition, in every period the exchange rate should make an adjustment in the form of a change that is equal to the size of the interest rate differential. In contrast to the theoretical equality above, in reality an exchange rate is likely to show short run deviations from the UIP and such deviations may reasonably be related to the size of the interest rate differential. This creates room for such deviations to factor into exchange rate volatility, and corresponding movements in interest rates are likely to affect the volatility of exchange rate. Although the effect of movements in interest rates is unclear, some theoretical ground for this is given by Bilson (1999), who shows that volatility of exchange rate is related to the difference between the interest rates of the two currencies. To account for nonlinearity in such a link, an ARCH-type model should be augmented by the squared interest rate differential $\left(i_{t}-i_{t}^{*}\right)^{2}$. Yet such a parameter alone might not be sufficient since it would capture the contemporaneous effect of the differential but not its dynamics. To remedy that, we opt for the second parameter in the form of an intertemporal change in interest rate differential squared $\left(\Delta\left(i_{t}-i_{t}^{*}\right)\right)^{2}$.

\subsection{Augmented TGARCH-M approximated volatility}

In empirical testing of exchange rate volatility we employ an augmented threshold GARCH-in-mean (TGARCH-M) model. Such specification has important extensions to the simple version of the GARCH model (due to Bollerslev, 1986) where volatility (conditional variance $\sigma_{t}^{2}$ ) is modelled as a function of the past squared innovations as well as its own

\footnotetext{
${ }^{19}$ It is possible to separate the interest rate differential into two variables-domestic and foreign interest rate. By separating them we would allow domestic and foreign interest rates to have different impacts on the exchange rate. This approach can be found in Svensson (1993) or Rose and Svensson (1994). We decide to
} 
past variance. First, the M-extension includes a conditional variance in the mean equation; this enables us to analyze the process with the path dependent rather than zero conditional mean. Second, the threshold extension accounts for asymmetric information. ${ }^{20}$ Inclusion of a leverage dummy, $d_{t}$, enables us to make a distinction between positive and negative shocks to volatility or for innovations to have an asymmetric effect on conditional volatility. Third, we augment the variance specification by the two parameters (interest rate differential and its intertemporal change) in order to isolate the effect of movements in interest rates on exchange rate volatility.

This results in the following specification of the augmented TGARCH-M model:

$$
\begin{aligned}
& \Delta s_{t}=a_{0}+\sum_{i=1}^{k} a_{i} \Delta s_{t-i}+b \ln \sigma_{t}^{2}+\lambda \cdot S D_{t}+\varepsilon_{t} ; \varepsilon_{t} \sim N\left(0, \sigma_{t}^{2}\right) \\
& \sigma_{t}^{2}=\omega+\sum_{i=1}^{p} \alpha_{i} \varepsilon_{t-i}^{2}+\sum_{j=1}^{q} \beta_{j} \sigma_{t-j}^{2}+\xi d_{t-1} \varepsilon_{t-1}^{2}+\delta_{1}\left(i_{t}-i_{t}^{*}\right)^{2}+\delta_{2}\left(\Delta\left(i_{t}-i_{t}^{*}\right)\right)^{2}
\end{aligned}
$$

where $\Delta s_{t}$ is the difference of the log of exchange rate between time $t$ and $t-1$ (exchange rate change over two consecutive trading days), and $k$ is the number of lags chosen by SchwarzBayesian lag selection criterion, as is the number of lags $p$ and $q$; the log of conditional variance in mean equation $\left(\ln \sigma_{t}^{2}\right)$ allows for an exponential rather than quadratic effect of observed volatility. The leverage effect dummy variable (TARCH term) $d_{t-1}$ is equal to 1 if $\varepsilon_{t-1}<0$ (negative shock or good news) and 0 otherwise (positive shocks or bad news) ${ }^{21}$; $\left(i_{t}-i_{t}^{*}\right)$ and $\left(\Delta\left(i_{t}-i_{t}^{*}\right)\right)$ are the annualized interest rate differential and the change in interest rate differential, respectively. The shock dummy $\left(S D_{t}\right)$ in the mean equation accounts for a few infrequent outliers of currencies' appreciation and depreciation movements and is described in detail in Section 5.

use the differential under the assumption that a change in domestic and foreign interest rate would have the same impact on the exchange rate and that only the level of interest rate differential plays an important role.

${ }^{20}$ The GARCH specification implies a symmetric impact of innovations on volatility. Whether innovation $\varepsilon_{t}$ is positive or negative makes no difference on the expected variance in the ensuing period. Only the size of the innovation matters - simply speaking it means that good news and bad news have the same effect. For example, the theory of leverage effect, first described in Black (1976) in connection with the stock market, suggests that positive and negative innovations have a different impact. Hence a large unanticipated drop in the market is expected to lead to higher volatility than a large unanticipated increase of comparable magnitude.

${ }^{21}$ The specification of volatility with leverage effect (represented by dummy variable $d_{t-1}$ ) was introduced by Glosten, Jagannathan, and Runkle (1993) and applied to exchange rates in the transition context by Kočenda (1998) and Orlowski (2003). In the case of the exchange rate, the leverage effect represents the fact that a decrease in the price of a foreign currency in terms of a domestic currency, or a domestic currency's appreciation, would tend to increase the subsequent volatility of the domestic currency more than would a depreciation of equal magnitude. 
In the above specification $\mathrm{ARCH}$ term $\alpha \varepsilon_{t-1}^{2}$ reflects the impact of 'news' or 'surprises' from previous periods that affect exchange rate volatility: significant, positive and less than one $\alpha$ depicts the extent of shocks that do not destabilize volatility. When $\alpha$ is greater than one then shocks materializing in the past are destabilizing. ${ }^{22}$ GARCH term $\beta \sigma_{t-1}^{2}$, on the other hand, measures the impact of the forecast variance from previous periods on the current conditional variance, or volatility. Significant coefficient $\beta$ (close to one) thus means a high degree of persistence in exchange rate volatility. The sum of both coefficients $(\alpha$ and $\beta$ ) indicates the speed of convergence of the forecast of the conditional volatility to a steady state: the closer to one its value is, the slower the convergence. TARCH asymmetric term $\xi d_{t-1} \varepsilon_{t-1}^{2}$ measures and accounts for the effect of the difference between good and bad news. The value of statistically significant leverage coefficient $\xi$ indicates the magnitude of the leverage effect, and the sign its direction. A positive value of coefficient $\xi$ indicates an increase - and a negative coefficient a decrease - in subsequent volatility of the exchange rate. Further, a negative value of the estimated coefficient means that negative shocks tend to raise subsequent volatility of exchange rate more than positive innovations of an equal magnitude. Finally, coefficients $\delta_{1}$ and $\delta_{2}$ capture the contemporaneous and intertemporal effects of the interest rate differential on exchange rate volatility. It is expected that the smaller the size of the interest rate differential, the smaller should be its effect on subsequent volatility.

Based on the information criteria (AIC and SIC) and significance of coefficients, we select a specific version of the baseline model (2) that best corresponds to data on each currency and regime, and report the results. Standardized residuals from such a specification are free from ARCH effects. Estimation of the model is performed by using a $\log$-likelihood function of the form $\ln L_{t}=-0.5\left(\ln \left(2 \pi \sigma_{t}^{2}\right)+\sum_{t=t_{0}}^{T} \varepsilon_{t}^{2} / \sigma_{t}^{2}\right)$ as in Bollerslev (1986). The maximum likelihood estimates are obtained by using the numerical optimization algorithm described by Berndt, Hall, Hall, and Hausman (1974). In order to avoid the risk of overestimating volatility we do not impose the i.i.d. normal distribution condition as is the case in many earlier studies. Rather, we allow for the generalized error distribution (GED) of Nelson (1991). The reason is that the exchange rate volatility series is very likely to follow a leptokurtic data distribution (as reflected by the actual GED 
parameter considerably lower than 2 , which is the value in the case of normal distribution). Empirical results presented in Section 6 show that this is a valid assumption. Leptokurtosis of daily exchange rate volatility implies that it tends to concentrate around the mean during tranquil market periods, while the shocks to volatility are very large during turbulent times. $^{23}$

\section{Data and Regime Switch}

We use daily nominal exchange rates expressed in terms of the euro ${ }^{24}$ to calculate changes in exchange rate over two consecutive periods in the currencies of the Visegrad Four. ${ }^{25}$ The interest rates of the Bundesbank and later of the European Central Bank (ECB) are used as a "foreign interest rate." We use daily interest rates of one-month maturity to calculate the needed interest rate differentials. In the literature we may also find shorter maturities used, but the one-month maturity is the maturity published in each country for the longest period. It is also close to a standard reference interest rate for most central banks. All data were assembled from statistics provided by the central banks of the countries under research for considerable periods before and after the regime was changed. In case of Slovakia we have gathered interest rate data (July-October 1997) from the ECOWIN Database since it was not readily available from the central bank. Length of the data varies depending on the extent of the particular regime; details on time span are given in Table 2.1.

Aside from similar developments in loosening their exchange rate regimes, our choice of the Visegrad Four countries reflects another factor that could influence exchange rate volatility, namely the credibility of the arrangement. In a spirit of the theoretical model of Krugman (1991), widening the fluctuation band should lead to an increase in the credibility of the band and consequently to a lowering in the volatility of the exchange rate.

\footnotetext{
${ }^{22}$ This condition is sufficient but not necessary. For a destabilizing effect we only need $\alpha+\beta \geq 1$, which is less strict.

${ }^{23}$ See Orlowski and Rybinski (2006) for a similar approach.

${ }^{24}$ In 1999 a common European currency, the Euro, replaced the national currencies of those countries that became members of the EMU.The euro started to serve in 1999 for banking or essentially non-cash transactions, and since 2002 for all transactions, including those made in cash. For the sake of consistency we use the official fixed parity ( 1 Euro $=1.95583$ Deutsch mark) to recalculate exchange rates for the pre-1999 period.

${ }^{25}$ We concentrate on the Visegrad Four group for practical reasons inherent to our analysis of volatility under different exchange rate regimes. Among post-transition accession countries, the Baltic countries have been maintaining fixed-type regimes for a long time without any reasonably long period of floating exchange rate regime. Slovenia has maintained a floating exchange rate regime de iure and a tightly managed crawling band regime de facto and, from the econometric point of view, we cannot use the short period of fixed-type exchange rate regime of this country's early transition.
} 
However, the credibility could be influenced by factors other than the width of the fluctuation band -- interest rate differential, inflation rate differential, or the level of foreign reserves, for example. The Visegrad Four show a high level of credibility; they either did not change the central parity or were doing so in pre-announced steps. By including countries that were forced to unexpectedly re-align their central parity many times, we would face the problem of how to include a credibility variable in our model. The careful choice of countries with similar credibility should diminish the effect of credibility on exchange rate in our analysis.

Since we want to analyze exchange rate volatility in conjunction with a move from a tighter to a looser exchange rate regime, the date of such a changeover seems to be the correct break point. However, the timing of the switch ought to be consistent with the departure from exchange rate-based monetary policies and not with the formal adoption of a pure float. For this reason we have to scrutinize each currency for an accurate date. This approach leads to a relatively uncomplicated choice for the Czech and Slovak currencies. After substantial periods of a currency basket peg the national banks introduced a floating regime on the following dates: May 26, 1997 in the Czech Republic and October 2, 1998 in Slovakia.

In the case of Poland the answer is less clearcut. The National Bank of Poland (NBP) had effectively already abandoned the exchange rate-based monetary policy in May 1995, long before switching to a pure float in April 12, 2000. The NBP had enacted in 1995 a crawling devaluation regime with a wide band of permitted fluctuations that was later expanded to $\pm 15 \%$. Such a wide band allowed the NBP to refrain from large foreign exchange market interventions, as it was capable of absorbing all nominal shocks, particularly those stemming from the Asian and Russian financial crises. After adopting a direct inflation targeting strategy in January 1999, the NBP gave up foreign exchange interventions almost entirely and further loosened its exchange rate policy when it introduced a wide fluctuation band of $\pm 15.0 \%$ on March 25, 1999. Therefore, we chose January 7, 1999 since it is a more appropriate choice for regime switching in Poland than is April 12, 2000 when the float was formally introduced. ${ }^{26}$

The National Bank of Hungary (NBH) has followed an ERM II shadowing strategy and adopted the forint/euro reference rate on January 1, 2000. The band was widened from

\footnotetext{
${ }^{26}$ We are grateful to an anonymous referee for clarifying this issue.
} 
$\pm 2.25 \%$ to $\pm 15.0 \%$ on May 4, 2001 and NBH adopted inflation targeting at this time. Although the crawling peg was abandoned only in October 2001, when the rate of crawl was set to zero, the rate of crawl was very low. As a matter of fact, the daily devaluation of the central parity amounted to $0.00654 \%$, which resulted in a total devaluation of $1.12 \%$ between May and October 2001 (Crespo-Cuaresma, Égert, and MacDonald, 2005). The overall impact of the crawl has been negligible and May 4, 2001 can be considered the effective date of exchange rate regime switch for the purpose of our analysis.

A change in exchange rate regime (or an important modification) represents a certain shock for the currency markets. Traders and central banks during the time before and shortly after the change react differently than during a "normal" period. During this period of change the exchange rate series have different statistical properties and contain many outliers-observations that do not come from the usual data-generating process. Therefore, we exclude from our dataset data for one month before the change of regime and one month after. Thus, our results should not contain any bias born of turbulent times. The basic statistics for exchange rate changes are found in Table 2.1 and for interest rates in Table 2.2.

Further, data for each country (and regime) include several observations that are clearly outside the normal data-generating process. These outliers usually correspond to a truly sudden change in a variable, or to other factors such as release of an unexpected macroeconomic indicator or short-term political turmoil (e.g. resignation of a minister). A standard GARCH model computes the next period's variance by squaring this period's shock. For very large shocks this approach produces dramatic increases in variance and distortion of coefficients. Friedman and Laibson (1989) argue that large shocks constitute extraordinary events and hence propose truncating their influence on the conditional variance. Charles and Darné (2005) make a case that the presence of outliers may have undesirable effects on the estimates of those equation parameters governing the volatility dynamics. We account for these extreme events by including a (shock) dummy variable $\left(S D_{t}\right)$ into the mean equation, rather than truncating the data. Using the classification of Hotta and Tsay (1998), this type of dummy accounts for additive outliers that only affect the level but leave the variance unaffected. In other words, these outliers do not influence the lagged disturbances that enter the conditional variance and, therefore, the variance equation 
remains free from any outliers that would affect the coefficients values. ${ }^{27}$ The shock dummy bears a value of one when the size of daily change in exchange rate is higher than five times the standard deviation of the sample and zero otherwise. The number of such shocks is extremely small and ranges from 2 to 6 . The exception is Hungarian forint under the float, where we find shocks to be present more often than in other countries and where we account for observations higher than two times the standard deviation. It is clear that the outliers we account for are quite infrequent when compared to the sample sizes of data used. Table 3 presents the facts on outliers in condensed form.

\section{Empirical findings}

Empirical results of the estimated volatility are presented in Tables 4-7. We first comment on results for each currency and then provide a brief summary. As a complement to the numerical outcomes we also provide graphical representation in Figures 1-4, where we plot conditional variance for all four currencies. The time-varying path of volatility delivers numerous insights on the responses of exchange rate risk to diverse general as well as specific external shocks. In general, under the fixed regime volatility is lower. Despite this, however, there are visible outbursts of volatility under both fixed and float regime periods. The Asian crisis in 1997, the Russian crisis in August 1998 and the Brazilian crisis in January 1999 provoked large shifts in the foreign exchanges and can be traced rather uniformly for all currencies.

\subsection{Volatility in Visegrad}

Table 4 contains results for the Czech Republic. A small, negative and significant coefficient of the (log of) conditional variance in the mean equation implies that exchange rate returns depended on the prevalent exchange rate risk under the tight regime. The negative coefficient means that an increase in volatility contributed to the currency's appreciation in terms of the euro but that such an effect was fairly limited. No effect of the volatility in the mean is found under the floating regime (coefficient not reported), which is positive news since volatility containment is therefore not a burning issue under the current regime. The estimated conditional variance equation shows that exchange rate risk is quite persistent under the tight regime, since the GARCH term coefficient is close to unity

${ }^{27}$ For other approaches to outlier detection see, for example, Doornik and Ooms (2005) in GARCH models and Giordani, Kohn and van Dijk (2006) or Battaglia and Orfei (2005) in general nonlinear time series 
(0.9307). The degree of persistence (0.8910) declines under the float in some way, though. Further, unanticipated "news" or "surprises" about volatility tend to increase the exchange rate risk at about an equal degree under both regimes as documented by $\mathrm{ARCH}$ term coefficients $(0.0612,0.0672)$. The sum of ARCH and GARCH coefficients is very close to unity under the tight regime (0.9919) and declines somewhat under the float (09582). Thus we argue that the exchange rate risk of the Czech koruna is converging to a steady state but very slowly indeed. Asymmetric shocks seem not to affect the currency's volatility since TARCH term coefficients are insignificant under both regimes. On the other hand, the impact of interest rate differential on volatility is evidenced under both regimes; regardless of the fact that the effect is fairly small, it nevertheless increases about four times under the float (0.0002 vs. 0.0009). Intertemporal change in interest differential does not affect exchange volatility whatsoever (coefficient not reported).

Aside from the uniform reasons for increases in volatility mentioned at the beginning of this section, there are more specific reasons related to each currency. Figure 1 shows conditional volatility developments in the Czech Republic. The effect of the Asian crisis was coupled with a local financial crisis that erupted on May 26, 1997. The mounting current account deficit and massive outflow of short-term capital prompted the Czech National bank (CNB) to relax the exchange regime towards the float since it was not willing to waste foreign exchange reserves on futile interventions. A subsequent credit crunch on the side of commercial banks was a major factor as well. The political crisis in 1998, when the government was recalled by the President for the first time in the history of the country (since 1918), and early elections in 1999 also affected volatility considerably. Such heightened volatility vanished only slowly, as is visible on the graph. A further increase in volatility in 2002, which continued into 2003, is most likely associated with significant deterioration in Czech fiscal discipline during this period.

The results for Slovakia are presented in Table 5 and yield rather different results from those detected in the case of the Czech Republic. An absence of significant coefficients of the conditional variance in the mean equation (not reported) implies that exchange rate returns are not greatly affected by the prevalent exchange rate risk under either regime. Exchange rate volatility has thus been quite well contained so far. A further difference is the originally higher degree of persistence in volatility measured by the 
GARCH term (0.9389), which decreases under the float (0.8525). Under the tight regime the volatility of the Slovak koruna was less affected by unexpected shocks than its Czech counterpart, since the ARCH term is lower (0.0442). Under the float this changes. Unexpected shocks tend to increase the exchange rate risk, as documented by the firstorder ARCH term coefficient (0.2390), and such an effect is dampened by more distant shocks as evidenced by the negative second-order ARCH term coefficient (-0.0986); this may likely come from purposeful adjustments of these shocks managed by the National Bank of Slovakia (NBS). A disturbing observation is the high sum of ARCH and GARCH coefficients that is not far from unity under the tight regime (0.9831) nor under the float (0.9928). This implies that the exchange rate risk of the Slovak koruna is converging to a steady state at an extremely slow rate and not decreasing. As in the Czech case, asymmetric shocks do not seem to affect the currency's volatility since the TARCH term coefficients are insignificant under both regimes. The effect of the interest rate differential is insignificant under the tight regime but is significant under the float and increases by an order of magnitude. As before, effects of interest differential changes are not found (coefficient not reported).

Figure 2 captures the development of the volatility of the Slovak koruna. During the fixed exchange rate regime volatility gradually rose from the beginning of 1997. This date coincides with an increase in the fluctuation band to $\pm 7.5 \%$ and with the start of excessive budgetary spending by the government. The Russian financial crisis in May 1997 coupled with crisis in the Czech Republic created pressure for exchange rate depreciation, but the central bank was able to maintain the fixed regime at the expense of a high level of interest rates and loss of foreign exchange reserves. This pressure on the exchange rate had gradually decreased towards the end of 1997. During the course of 1998, mounting government deficits (around 6\% of GDP) put pressure on demand for the koruna and resulted in very high interest rates that enabled the NBS to support the existence of the fixed regime for an additional year. However, shortly before parliamentary elections (September 1998) it became clear that abandoning the fixed regime would be inevitable. This expectation increased volatility and finally, a few days after election results were announced, the fixed exchange rate regime was replaced with a floating one. The burgeoning economic crisis and change in exchange rate regime increased volatility at the end of 1998. The new government, unfortunately, did not start the reform process as quickly as was expected by the financial markets. In May 1999 the government, after strong 
depreciation pressure, announced a series of measures that helped to stabilize the economy. After this date, the majority of spikes in volatility are connected either with political turmoil (a referendum on early elections in November 2000 and April 2004, the presidential election in May 1999 and April 2004, regular parliamentary elections in September 2002 with positive results, and political instability in June 2003) or with central bank intervention on the foreign exchange market. Besides these internal factors, the Slovak foreign exchange market is often driven by regional news or sentiment. In this case, problems experienced by the other Visegrad countries described above and below apply to Slovakia as well.

Table 6 contains the results for Hungary. Under the fixed regime the volatility did not affect the development of returns (insignificant coefficient not reported). The effect of ( $\log$ of conditional) variance in the mean equation is evident under the floating regime, though. Its negative coefficient (-0.0013) means that the increase in volatility contributed to the currency's appreciation in terms of the euro; such an effect being limited due to the coefficient's size, though. The estimated conditional variance equation shows that exchange rate risk was not as persistent under the tight regime as it was in the Czech or Slovak cases since the GARCH term coefficient is below unity (0.7981). The degree of persistence increases somewhat under the float (0.8555), though. Unanticipated "news" or "surprises" about volatility that are captured by the ARCH coefficient show their tendency to increase exchange rate risk under the tight regime (0.3050) three times more in comparison with the float (0.1060). The sum of the ARCH and GARCH coefficients is above unity under the tight regime (1.1031) but declines below one under the float (0.9615). The exchange rate risk of the forint, therefore, has been converging to a steady state only under the float regime but such convergence has been very slow. Asymmetric shocks, captured by the TARCH term, do affect the currency's volatility quite strongly under both regimes. The negative coefficients mean that asymmetric shocks tend to dampen the volatility, albeit less under the float $(-0.1345)$ than under the tight regime $(-0.2089)$. The impact of the interest rate differential on volatility is seen under both regimes. As in the previous case, this effect is small but its importance heightens dramatically under the float (0.0009) as the coefficient increases about eight times in comparison to the tight regime (0.00012). Again, intertemporal change in the interest differential does not affect exchange volatility at all (coefficient not reported). 
Figure 3 depicts the volatility path in Hungary. The effect of the two major crises (1997, 1998) mentioned above is clearly visible during the fixed regime period, as well as is the Brazilian currency devaluation and crisis in 1999. Volatility then greatly decreased after the basket was reduced to a peg to the euro in January 2000. With the widening of the fluctuation band in May 2001 volatility has risen considerably. The single year 2003 hosted three major events that prompted outbursts of volatility. A jump in volatility in January 2003 is associated with an attack against the Hungarian forint (HUF) on its strong end. A significant jump in volatility in mid-2003 coincides with a badly coordinated devaluation of the central parity of the Hungarian forint on June 4, 2003 by $2.26 \%$ against the euro accompanied by confusing statements from the central bank and government, which initiated quite an amount of depreciation and elevated volatility past this step visible on the plot. Finally, in December 2003 an attack against the HUF on its weak end prompted the largest jump in volatility not only in that year but during the period of the semi-floating regime so far.

Results for the Polish currency are given in Table 5 and provide evidence that despite numerous similarities, the path of volatility in all four countries is quite different. The significant coefficient of the conditional variance in the mean equation implies that exchange rate returns were affected by the prevalent exchange rate risk under the tight regime but that such an effect has not been found under the float (coefficient not reported). The exchange rate volatility has thus been well contained since the regime was relaxed. The degree of the volatility's persistence as measured by the (sum of) the GARCH term was markedly lower under the tight regime (0.5061) than under the float $(0.7760)$. Under the tight regime, the persistence was dampened by the first-order GARCH term $(-0.1499)$, but more than outweighed by the second-order one $(0.6560)$. Of the four countries, the persistence of the Polish zloty has been the lowest in general, though. Under both regimes the currency has been affected by unexpected shocks, though far more under the tight regime than under the float as can be seen from the values of the ARCH term $(0.3164$, 0.1535). Such an effect is divided into two periods, where the second-order ARCH effect is even stronger than the first-order one, indicating a cumulative effect of the shocks and some degree of memory on the market. More disturbing is that the sum of the ARCH and GARCH coefficients increased greatly from one regime to the next. The sum's relatively low value under the tight regime $(0.8225)$ increased, but nevertheless stayed below one (0.9295) under the float. Thus, convergence of the zloty toward a steady state considerably 
slowed down under the float. Asymmetric shocks also affect the currency's volatility in a different way than in the case of the Hungarian forint. The TARCH term coefficient is positive under the tight regime (0.0134) and negative under the float $(-0.1611)$. Thus, asymmetric shocks tend to increase the currency's volatility under the former regime and decrease it under the latter one; the dampening effect is more than ten times stronger, though. Also, under both regimes the effect of interest rate differential is significant and of almost equal magnitude. As before, the effect of interest differential change is not found (coefficient not reported).

As can be seen from Figure 4, in Poland the effect of the Asian crisis (1997) was quite limited and the outburst of volatility did not last long; this was also empirically shown by Gelos and Sahay (2001). The heightened volatility in September 1998 can undoubtedly be attributed to the official strategy of "de-coupling" the Polish financial markets and institutions from the Russian crisis. The monetary authorities presented compelling evidence of immunity to possible contagion effects of the crisis by emphasizing the better institutional advancement of its financial system and the higher quality of assets held by the country's financial institutions (Orlowski, 2004). During the float regime period the volatility spikes in July 2000 and again in summer 2001 related to uncertainties about parliamentary approval of the budget. If the budget proposals did not get approved, Poland would have to borrow additional funds in eurobond markets. Official government statements on these needs triggered some speculative actions against the Polish zloty with increased volatility as a consequence. More recently in early 2005, the spike had a different nature as it was related to the zloty's appreciation. This shows up because the conditional variance equation contains interest rate differentials as regressors. The NBP had been slowly cutting the interest rates in 2005, while the zloty appreciated significantly in euro (and USD) terms. This was particularly due to the Ministry of Finance's extensive selling of the proceeds from eurobonds on foreign exchange markets in exchange for domestic currency. ${ }^{28}$

\subsection{Volatility patterns}

To summarize, volatility in the exchange rates of the Visegrad Four countries followed very different patterns; this result challenges the common conception that views the four

\footnotetext{
${ }^{28}$ We thank Lucjan Orlowski for sharing his insights with us.
} 
countries as a rather homogenous group. This finding is further corroborated by the correlations for exchange rate volatility presented in Table 8. Correlation coefficients are calculated over the common sample for all currencies under specific exchange rate regimes. The length of the sample is 160 and 958 observations for fixed and floating regimes, respectively. The correlation is very low and further decreases under the float. Frequently coefficients are negative. Some co-movements in volatility, albeit low, can be traced for pairs of the Czech and Slovak korunas and Polish zloty-Slovak koruna. This supplementary evidence means that exchange rate volatility has been driven chiefly by country specific factors rather than common causes.

Volatility increased or remained about the same after the tight regimes were replaced with more flexible ones. These findings are broadly in line with the stylized fact that volatility is greater under a float than under a fix. When considering that all four countries under study practiced inflation targeting during the flexible regime period, this result is also in line with the theoretical outcome of Leitemo (2004), who argued that such targeting would lead to excessive interest rate and exchange rate volatility. ${ }^{29}$ Future entry to the ERM II with a wide $( \pm 15 \%)$ band should lead to lower volatility, and hence potential conflict with inflation targeting need not materialize. ${ }^{30}$ The crucial matter is the reference exchange rate of each currency to the euro at time of entry. An inappropriate reference rate - a rate not reflecting macroeconomic developments nor market sentiment - would induce pressures that would tend to increase its volatility and potentially violate ERM II boundaries.

Both ARCH and GARCH terms have statistically significant coefficients under both types of regimes, which enable unambiguous comparisons. Coefficient $\alpha$ represents the reaction of volatility to news and surprises. During the period of flexible regimes its value increased in the Czech and Slovak Republics, indicating that the extent to which volatility was driven by surprises gained magnitude with respect to the previous period of tight regimes. The value of the coefficient, on the other hand, decreases in Poland and Hungary.

Coefficient $\beta$ represents the degree of persistence in volatility. While the degree is quite high, it decreased in the Czech and Slovak Republics. This decrease in persistence can

\footnotetext{
${ }^{29}$ Leitemo (2004) studied interest rate and exchange rate dynamics as a game between monetary and fiscal policymakers, where the monetary policymaker targets inflation. In the Nash game, a conflict over the appropriate size of the output gap leads to excessive interest rate and exchange rate volatility.

${ }^{30}$ See Orlowski and Rybinski (2006) for a discussion of the implications of ERM II for Poland's monetary policy framework.
} 
be considered a positive sign and can be understood as the result of lower pressure on exchange rate movements after the move from tighter exchange rate management. The persistence increased in Hungary and Poland. On the other hand its degree is at lower (Poland) or comparable (Hungary) levels than it is in the former two countries.

Coefficient $\xi$ of the asymmetric term illustrates the reaction of volatility to different categories of news. A negative and significant coefficient in the case of the Hungarian forint shows a substantial suppressing effect of bad news (positive shocks) on this currency's volatility during both regimes; the effect is somewhat smaller after the exchange regime was relaxed. The formerly positive coefficient in Poland indicates that the bad news (positive shocks) had a mild increasing impact on volatility during the tight regime period, while under the float this changes into a suppressing effect. In the case of the Czech and Slovak korunas the coefficients are insignificant under both regimes.

The sum of the ARCH and GARCH terms' coefficients indicates the degree of convergence to a steady state. The degree of convergence is uniformly slow for all four currencies, although certain improvements can be seen in the case of the Czech koruna and Hungarian forint. However, for the Hungarian forint this is not a marginal improvement since under the tight regime the sum was greater than one, thus indicating a divergent process. In Poland the exchange risk increased quite dramatically but the movement to the steady state is still slightly faster than in any of the remaining three countries. Truly disturbing is the development of the Slovak koruna, whose exchange risk under the float is moving from the steady state; the sum of the coefficients exceeds unity. In light of the fact that Slovakia entered the ERM II regime on November 27, 2005 such instability is troubling. We can only speculate whether the NBS was aware of the nature of the volatility's development prior to taking this important step towards the euro.

Dependency of exchange volatility on interest rate differential movements shows that under both regimes the level of interest rate differential $\left(\delta_{l}\right)$ affects the volatility of all four currencies (contemporaneous effect); the only exception is the case of the Slovak koruna under the fixed regime. This result is in line with the findings of Bilson (1999), as the high interest rate differential should be accompanied by higher exchange rate volatility in order to meet with the no arbitrage condition of international financial markets. Further, after floating was introduced, the effect of the interest rate differential increased, with the exception of Poland where it remained about the same. On the other hand, the intertemporal effect of the interest rate differential was not detected for any currency under either regime. 


\section{Conclusions}

We analyze the volatility of exchange rates in the Visegrad Four countries: the Czech Republic, Hungary, Poland, and Slovakia. We compare volatilities in the currencies under specific exchange rate regimes, and use an augmented path-dependent threshold GARCH specification (TGARCH-M) to evaluate the dependency of exchange rate on its volatility and to uncover the effects of external shocks and interest rates on exchange rate volatility, as well as its persistence and tendency towards a steady state.

Our findings show that daily returns on the Czech and Polish currencies depended on the prevalent exchange rate risk under the tight regime, while the Hungarian currency is affected by its volatility under the float; there is no evidence for Slovakia. Such findings imply that exchange rate risk has not been well contained in the past, but that only the Hungarian currency is affected under the current regime. It should be noted that in all three cases volatility contributes to the appreciation of the currency, which is usually considered not that harmful when compared with depreciation pressures.

Results from estimated conditional volatility show that after a major switch in exchange regime has taken place, volatility tends to increase. This finding is generally in line with the stylized fact that exchange volatility is greater under a flexible regime than under a tight one. Further, the result of external shocks, news or surprises, on exchange volatility is not uniform and differs across countries; volatility has been driven primarily by country specific reasons. The extent to which the volatility was driven by shocks increased under the float for the Czech and Slovak currencies, while it decreased for the Hungarian and Polish ones. In this respect the central banks of Poland and Hungary are in a better position since their currencies are better able to contain external shocks, possibly due to more developed financial markets. The opposite is true for volatility persistence: it decreased in the case of the former countries (korunas) and decreased for the latter ones (zloty and forint). A decrease in persistence can be considered a positive sign. On the other hand, the persistence has been at roughly the same level for all four currencies under the float, and in this respect none of them is "better" than any other. The asymmetric effect of past shocks yields mixed results under the tight regime, but its uniformly suppressing role is documented under the float. ${ }^{31}$

\footnotetext{
${ }^{31}$ This evidence is available for Hungary and Poland; other coefficients are insignificant.
} 
Two results merit specific attention. First, the contemporaneous effects of interest rate differentials (on exchange rate volatility) are small, but clearly present, and increase under the float. The effects of changes in interest differentials do not materialize, though. This result makes sense for several reasons. During the period of tighter regimes, transition countries largely did not conduct an independent monetary policy. But after abandoning tighter regimes, the monetary policies of these countries became more independent and the interest rate became its key instrument. Further, the level of interest rates for the Visegrad countries was relatively high during the tighter regime period. A high interest rate should, ceteris paribus, cause appreciation of the currency (within the bands of the currency basket and crawling pegs). However, in the case that a high nominal interest rate reflects a high expected inflation rate (as was the case), the currency is expected to lose value in the future (Frankel, 1993). Therefore, if the level of the interest rate (or its differential) mirrors the uncertain economic situation of the country proxied by the presence of high inflation, there should materialize the effect of interest rate enhancing exchange rate volatility, which is in fact what we found.

Second, convergence of exchange rate volatility to the steady state is the least straightforward outcome. When the two regimes are compared, convergence rate increased as well as decreased, depending on the currency. Altogether, it has been relatively slow and at about equal footing for three currencies. The exception is the Slovak koruna, whose volatility tends to diverge from the steady state. All four countries should strive to limit their currencies' volatility by enhancing institutions critical to functioning financial markets as well as to remedy weaknesses discussed earlier as sources of volatility. Since Slovakia has already entered the ERM II stage, it should lead the pack, but its diverging trend seems to be a serious drawback.

In general, results from both methods lead to the conclusion that the width of the fluctuation band, either narrow or broad, does not necessarily mean an unambiguous influence on exchange rate fluctuation. There can be various factors that affect the volatility of exchange rate other than the type of exchange rate regime. However, the type of regime is likely the strongest factor as is the role interest rate plays in exchange rate volatility.

Our findings show that policy makers should work to contain exchange rate volatility. One good reason is related to the large openness of the Visegrad economies and their dependency on foreign trade. Higher volatility under the float might have negative effects on international trade; these effects were documented by Égert and Morales- 
Zumaquero (2005) for the past. Increased foreign exchange volatility may also dampen the pass-through from exchange rate to inflation, which may have a potentially negative impact on the ongoing process of convergence in prices to EU15 levels. Specifically, increased volatility associated with a more flexible exchange rate regime, together with the inflation targeting framework, may break the link between exchange rate and prices by disconnecting primarily non-tradable goods from the exchange rate (Coricelli, Jazbec, and Masten, 2006).

Further, when we connect spikes of volatility with real events it is evident that volatility is not a completely exogenous process. Budgetary imbalances are probably the most critical issue in the Visegrad Four countries that affect not only exchange rate volatility but the entire process of conversion to the EMU (see Kočenda, Kutan, and Yigit, 2005, for a thorough assessment), and government deficits are in the hands of policymakers. In any event, the uncertain position of fiscal discipline works as a common exogenous factor behind exchange rate volatility. Further, central banks should set low inflation targets, gain their credibility, and stabilize nominal interest rates at low levels. A stable interest rate propagates less volatility in exchange rate, and achieving stable low inflation promotes a less volatile exchange rate as well, which is in accord with Orlowski (2004). This, however, constitutes a risk of expectations for a nominal exchange rate appreciation trend which may paradoxically strengthen exchange volatility. To avoid such a convergence game it is imperative to create a consistent framework for monetary policy decisions. Even more importantly, central banks should enhance communication of their policy decisions and targets to the markets (Woodford, 2005). Such an approach should reduce the frequency of unexpected news as well as surprises with respect to monetary policy steps and instruments. Hence, it would reduce those major factors that have driven exchange volatility in the Visegrad countries. From the two major areas above it follows that coordination of monetary and fiscal policies might help to reduce exchange volatility the most. In the current world, we are afraid that this would be asking too much. 


\section{References}

Andersen, T. G., Bollerslev, T., Diebold, F. X., and P. Labys, 2001, "The distribution of realized exchange rate volatility", Journal of the American Statistical Association, 96 (453):42-55.

Andersen, T. G. and Bollerslev, T., 1998. Deutsche Mark-Dollar Volatility: Intraday Activity Patterns, Macroeconomic Announcements, and Longer Run Dependencies, Journal of Finance 5391): 219-265.

Babetskii, I., 2005. Trade integration and synchronization of shocks. Implications for EU enlargement, Economics of Transition 13(1), 105-138

Battaglia, F. and L. Orfei, 2005, Outlier detection and estimation in nonlinear time series, Journal of Time Series Analysis 26, 107-121.

Berndt, E. K., Hall, B. H., Hall, R. E. and J.A. Hausman, 1974, "Estimation of inference in nonlinear structural models", Annals of Economic and Social Measurement 4: 653665.

Bilson, J. F.O., 1999, “The non-linear dynamics of exchange rates”, Working Paper, Stuart Graduate School of Business, Illinois Institute of Technology.

Black, F., 1976, "Studies of stock market volatility changes", 1976 Proceedings of the American Statistical Association, Business and Economic Statistics Section, 177181.

Bofinger, P. and T. Wollmershäuser, 2001, Is there a third way to EMU for the EU accession countries?, Economic Systems 25, 253-274

Bollerslev, T., 1986, "Generalized autoregressive conditional heteroscedasticity", Journal of Econometrics 31: 307-327.

Charles, A. and O. Darné, 2005. Outliers and GARCH models in financial data, Economics Letters 86 (2005) 347-352.

Chinn, M.D., 2006. The (partial) rehabilitation of interest rate parity in the floating rate era: Longer horizons, alternative expectations, and emerging markets, Journal of International Money and Finance 25(1), 7-21.

Coricelli, F., B. Jazbec, and I. Masten, 2006. Exchange Rate Pass-Through in EMU Acceding Countries: Empirical analysis and policy implications, Journal of Banking and Finance, forthcoming. 
Crespo-Cuaresma, J., Balázs Égert, and Ronald MacDonald, 2005. "Non-Linear Exchange Rate Dynamics in Target Zones: A Bumpy Road towards a Honeymoon," William Davidson Institute Working Paper No. 771.

Detragiache, E., Mody, A., Okada, E., 2005. Exits from heavily managed exchange rates. International Monetary Fund Working Paper No. WP/05/39.

Doornik Jurgen A. and Marius Ooms, 2005, Outlier Detection in GARCH Models, Tinbergen Institute Discussion Paper TI 2005-092/4.

Égert, B., 2003. Equilibrium real exchange rates in CEE acceding countries: Can we have DEER with BEER without FEER? A critical survey of the literature, Oesterreichische Nationalbank, Focus on Transition, No. 2.

Égert, B. and A. Morales-Zumaquero, 2005, Exchange Rate Regimes, Foreign Exchange Volatility and Export Performance in Central and Eastern Europe: Just Another Blur Project?, William Davidson Institute Working Paper No. 782.

Engle, R. F., 1982, Autoregressive Conditional Heteroskedasticity with Estimates of the Variance of United Kingdom Inflation, Econometrica 50, 987-1007.

Figlewski, S., 1997, "Forecasting volatility”, Financial Markets, Institutions, \& Instruments $6(1), 1997$.

Frankel, J.A., 1993. International Financial Integration: Relations between Interest Rates and Exchange Rates. In Das, D.K. (ed.) International finance: Contemporary issues. London and New York: Routledge, pp. 333-59

Friedman, Benjamin M. and David I. Laibson, 1989, "Economic implications of extraordinary movements in stock prices." Brookings Papers on Economic Activity 2, 137-189.

Gelos, R.G., Sahay R., 2001. Financial market spillovers in transition economies. Economics of Transition, 9 (1), 53-86.

Giordani, P., R. Kohn and D. van Dijk, 2006. A unified approach to nonlinearity, outliers and structural breaks, Journal of Econometrics, forthcoming.

Glosten, L., Jagannathan, R., and D. Runkle, 1993, "On the relationship between the expected value and the volatility of the nominal excess returns on stocks", Journal of Finance 48(5), 1779-1801

Golinelli, R. and Riccardo Rovelli, 2002. Painless disinflation? Monetary policy rules in Hungary, 1991-99, Economics of Transition 10(1), 55-91. 
Golinelli, R. and Riccardo Rovelli, 2005. Monetary policy transmission, interest rate rules and inflation targeting in three transition countries, Journal of Banking and Finance 29(1), 183-201.

Hallett, A.H. and M.L. Anthony, 1997, "Exchange rate behavior under the EMS regime: Was there any systematic change?", Journal of International Money and Finance 16(4), August.

Hau, H., 2002, „Real exchange rate volatility and economic openness: Theory and evidence," Journal of Money, Credit and Banking, 34(3):611-630.

Hotta, L. K. and R. S. Tsay, 1998, Outliers in GARCH processes. Working Paper, University of Chicago.

Jorion, P., 1995. Predicting volatility in foreign exchange market, Journal of Finance 50(2): 507-528.

Kanas, A., 2005. Regime Linkages in the US/UK Real Exchange Rate-Real Interest Differential Relation, Journal of International Money and Finance 24(2), 257-74.

Kemme, D.M. and W. Teng, 2000. Determinants of the Real Exchange Rate, Misalignment and Implications for Growth in Poland, Economic Systems, 24(2): 171-205

Kočenda, E., 1998. Altered Band and Exchange Volatility. Economics of Transition, 6(1), 173-181.

Kočenda, E., 2001. Macroeconomic Convergence in Transition Economies, Journal of Comparative Economics, 29(1), 1-23.

Kočenda, E., 2002. Exchange Rate Movements in European Transition Economies. In: Columbus, F. (ed.) European Economic and Political Issues 5, Nova Science Publishers, New York, 2002, p. 27-48.

Kočenda, E., 2005. Beware of Breaks in Exchange Rates: Evidence from European Transition Countries. Economic Systems 29(3), 307-324.

Kočenda, E, Kutan, A.M., Yigit, T.M., 2005. Pilgrims to the Eurozone: How Far, How Fast? CERGE-EI Working Paper No. 279.

Kmenta, J., 1990, Elements of Econometrics, Macmillan Publishing 2nd edition.

Krugman P.R., 1991, “Target zones and exchange-rate dynamics”, Quarterly Journal of Economics 106: (3) 669-682, August.

Kutan, A. and T. Yigit, 2004. Nominal and Real Stochastic Convergence of Transition Economies. Journal of Comparative Economics, 32, 23-36. 
Leitemo, K., 2004. A Game between the Fiscal and the Monetary Authorities under Inflation Targeting, European Journal of Political Economy, 20(3): 709-724

Mussa, M., 1986, "Nominal Exchange Rates Regimes and the Behavior of Real Exchange Rates: Evidence and Implications", Carnegie-Rochester Conferences on Public Policy, 25, 117-214.

Nelson, D. B., 1991. Conditional heteroskedasticity in asset returns: A new approach. Econometrica 59, 347-370.

Orlowski, L.T., 2000a. Direct inflation targeting in central Europe. Post-Soviet Geogr. Econ. 41, 134-154.

Orlowski, L.T., 2000b. Monetary policy regimes and real exchange rates in Central Europe's transition economies. Economic Systems 24, 145-166.

Orlowski, L.T., 2001. From inflation targeting to the euro-peg. A model of monetary convergence for transition economies. Economic Systems 25, 233-251.

Orlowski, L.T., 2003. Monetary Convergence and Risk Premiums in the EU Accession Countries. Open Economies Review 14: 251-267

Orlowski, L.T., 2004. Exchange Rate Risk and Convergence to the Euro. ZEI Working Paper no. B 25/2004.

Orlowski, L.T., 2005. Monetary convergence of the EU accession countries to the Eurozone: A theoretical framework and policy implications. Journal of Banking and Finance, 29, (1), 203-225

Orlowski, L.T. and K. Rybinski, 2006. Implications of ERM II for Poland's Monetary Policy Framework. Mimeo, presented at the AEA/ACES Conference, January 2006, Boston

Papell, D.H., 1992, "Can Equilibrium Models Explain Nominal Exchange Regime Nonneutrality? Evidence from the European Monetary System”, Journal of International Money and Finance, 11, 96-106.

Rose, A.K. and L.E.O. Svensson, 1994, "European exchange rate credibility before the fall”, European Economic Review, 38:1185-1216.

Scott, E. and Tucker, A., 1989. Predicting Currency Return Volatility, Journal of Banking and Finance 13: 839-851.

Schadler, S., 2004. Charting a course toward successful euro adoption. Finance and Development 41(2), 29-33. 
Stockman, A., 1988, "Real Exchange-rate Variability under Pegged and Floating Nominal Exchange-rate Systems: An Equilibrium Theory", Carnegie-Rochester Conferences on Public Policy, 29, 259-294.

Svensson, L.E.O., 1993, “Assessing target zone credibility: Mean reversion and devaluation expectations in the ERM, 1979-1992", European Economic Review, 37:763-802.

Svensson, L.E.O., 1999. Inflation targeting as a monetary policy rule. J. Monet. Econ. 43, $607-654$.

Svensson, L.E.O., 2000. Open-economy inflation targeting. Journal of International Economics 50, 155-183.

Szapary, G. and Z. Jakab, 1998. Exchange Rate Policy in Transition Economies: The Case of Hungary, Journal of Comparative Economics 26(4): 691-717

Vinhas de Souza, Lucio, 2002. Integrated Monetary and Exchange Rate Frameworks, Tinbergen Institute Working Paper No. 2002-054/2.

Woodford, Michael, 2005. Central Bank Communication and Policy Effectiveness, NBER Working Paper No. 11898. 
Table 1

Exchange Rate Regime Development

A: Czech Republic

Changes to koruna exchange regime

\begin{tabular}{|l|l|}
\hline 1 January 1991 & $\begin{array}{l}\text { Currency basket peg regime, Basket: 45.52\% DEM, 31.34\% USD, } \\
12.35 \% \text { ATS, 4.24\% GBP, 6.55\% CHF }\end{array}$ \\
\hline 2 January 1992 & $\begin{array}{l}\text { Change in Basket composition: 36.15\% DEM, 49.07\% USD, } \\
8.07 \% \text { ATS, 2.92\% FRF, 3.79\% CHF }\end{array}$ \\
\hline 8 February 1993 & $\begin{array}{l}\text { Split of Czechoslovak currency - Czech koruna. No change in } \\
\text { basket composition or band width }\end{array}$ \\
\hline 3 May 1993 & Basket 65\% DEM, 35\% USD, Band $\pm 0.5 \%$ \\
\hline 28 February 1996 & Widening band to $\pm 7.5 \%$ \\
\hline 26 May 1997 & $\begin{array}{l}\text { Introduction of managed float with reference currency DEM and } \\
\text { later EUR }\end{array}$ \\
\hline
\end{tabular}

B: Poland

Changes to zloty exchange regime

\begin{tabular}{|l|l|}
\hline 1 January 1990 & Exchange rate fixed to dollar. 1USD=9500 ZLP \\
\hline 16 May 1991 & $\begin{array}{l}\text { Exchange rate fixed to a currency basket (45\% USD, 35\% DEM, } \\
10 \% \text { GBP, 5\% FRF, 5\% CHF), devaluation to 1USD=11100ZLP } \\
(16.84 \%)\end{array}$ \\
\hline 14 October 1991 & $\begin{array}{l}\text { Crawling peg to the currency basket: crawling rate 1.8\% monthly, } \\
\text { NBP margin }+/-0.6 \%\end{array}$ \\
\hline 26 February 1992 & Devaluation by 12\% + maintain crawling peg 1.8\% \\
\hline 27 August 1993 & Devaluation by 7.4\% + Crawling rate 1.6\% \\
\hline 13 September 1994 & Crawling peg 1.5\% monthly \\
\hline 30 November 1994 & Crawling peg 1.4\% \\
\hline 16 February 1995 & Crawling peg 1.2\% \\
\hline 6 March 1995 & NBP margin $+/-2 \%$ \\
\hline 16 May 1995 & $\begin{array}{l}\text { Introduction of crawling band }+/-7 \%, \text { crawling rate 1.2\%, } \\
\text { interbank rates subject to free market forces and NBP } \\
\text { intervention }\end{array}$ \\
\hline 22 December 1995 & Revaluation by 6\% \\
\hline 8 January 1996 & Crawling peg 1.0\% \\
\hline 26 February 1998 & Crawling peg 0.8\% and band +/- 10\% \\
\hline 17 July 1998 & Crawling peg 0.65\% \\
\hline 10 September 1998 & Crawling peg 0.5\% \\
\hline 28 October 1998 & Band +/- 12.5\% \\
\hline 1 January 1999 & Change in currency basket: euro 55\%, dollar 45\% \\
\hline 25 March 1999 & Crawling peg 0.3\%, band +/- 15\% \\
\hline 7 June 1999 & $\begin{array}{l}\text { NBP is not obliged to perform transactions with commercial } \\
\text { banks during fixing }\end{array}$ \\
\hline 12 April 2000 & Floating exchange rate \\
\hline
\end{tabular}




\section{C: Hungary}

Changes in basket and width of the forint intervention band

\begin{tabular}{|l|l|}
\hline 26 February 1990 & USD 42,6\%, DEM 25,6\%, ATS 10,4\%, CHF 4,9\%, ITL 3,8\%, \\
& FRF 3,5\%, GBP 2,9\%, SEK 2,0\%, NLG 1,7\%, FIM 1,5\%, BEC \\
& $1,1 \%$ \\
\hline 14 March 1991 & USD 50,9\%, DEM 23,1\%, ATS 8,1\%, CHF 3,9\%, ITL 3,5\%, FRF \\
& $3,6 \%$, GBP 2,7 \%, SEK 1,5\%, NLG 2,7\% \\
\hline 9 December 1991 & USD 50\%, ECU 50\% \\
\hline 1 July 1992 & Band width $\pm 0.3 \%$ \\
\hline 2 August 1993 & USD 50\%, DEM 50\% \\
\hline 16 May 1994 & USD 30\%, ECU 70\% \\
\hline 1 June 1994 & Band width $\pm 0.5 \%$ \\
\hline 5 August 1994 & Band width $\pm 1.25 \%$ \\
\hline 22 December 1994 & Band width $\pm 2.25 \%$ \\
\hline 1 January 1997 & USD 30\%, DEM 70\% \\
\hline 1 January 1999 & USD 30\%, EUR 70\% \\
\hline 1 January 2000 & EUR 100\% \\
\hline 4 May 2001 & Band width $\pm 15.00 \%$ \\
\hline
\end{tabular}

Official devaluations of forint

\begin{tabular}{|c|c|c|c|}
\hline 31 January 1990 & $1.0 \%$ & 29 November 1994 & $1.0 \%$ \\
\hline 6 February 1990 & $2.0 \%$ & 3 January 1995 & $1.4 \%$ \\
\hline 20 February 1990 & $2.0 \%$ & 14 February 1995 & $2.0 \%$ \\
\hline 7 January 1991 & $15.0 \%$ & 13 March 1995 & $9.0 \%$ \\
\hline 8 November 1991 & $5.8 \%$ & 16 March 1995 & $\begin{array}{r}1.9 \% \text { (rate of daily devaluation: } \\
0.060 \%)\end{array}$ \\
\hline 16 March 1992 & $1.9 \%$ & 29 June 1995 & $\begin{array}{r}1.3 \% \text { (rate of daily devaluation: } \\
0.042 \% \text { ) }\end{array}$ \\
\hline 24 June 1992 & $1.6 \%$ & 2 January 1996 & $\begin{array}{r}1.2 \% \text { (rate of daily devaluation: } \\
0.040 \% \text { ) }\end{array}$ \\
\hline 9 November 1992 & $1.9 \%$ & 1 January 1997 & $\begin{array}{r}1.2 \% \text { (rate of daily devaluation: } \\
0.040 \% \text { ) }\end{array}$ \\
\hline 12 February 1993 & $1.9 \%$ & 1 April 1997 & $\begin{array}{r}1.1 \% \text { (rate of daily devaluation: } \\
0.036 \% \text { ) }\end{array}$ \\
\hline 26 March 19932 & $.9 \%$ & 15 August 1997 & $\begin{array}{r}1.0 \% \text { (rate of daily devaluation: } \\
0.033 \% \text { ) }\end{array}$ \\
\hline 7 June 1993 & $1.9 \%$ & 1 January 1998 & $\begin{array}{r}0.9 \% \text { (rate of daily devaluation: } \\
0.030 \% \text { ) }\end{array}$ \\
\hline 9 July 1993 & $3.0 \%$ & 15 June 1998 & $\begin{array}{r}0.8 \% \text { (rate of daily devaluation: } \\
0.026 \% \text { ) }\end{array}$ \\
\hline 29 September 1993 & $4.5 \%$ & 1 October 1998 & $\begin{array}{r}0.7 \% \text { (rate of daily devaluation: } \\
0.023 \% \text { ) }\end{array}$ \\
\hline 3 January 1994 & $1.0 \%$ & 1 January 1999 & $\begin{array}{r}0.6 \% \text { (rate of daily devaluation: } \\
0.020 \% \text { ) }\end{array}$ \\
\hline 16 February 1994 & $2.6 \%$ & 1 July 1999 & $\begin{array}{r}0.5 \% \text { (rate of daily devaluation: } \\
0.0163 \% \text { ) }\end{array}$ \\
\hline
\end{tabular}




\begin{tabular}{|l|r|}
\hline 13 May 1994 & $1.0 \%$ \\
\hline 10 June 1994 & $1.2 \%$ \\
\hline 5 August 1994 & $8.0 \%$ \\
\hline 11 October 1994 & $1.1 \%$ \\
\hline & \\
\hline
\end{tabular}

\begin{tabular}{|l|r|}
\hline 1 October 1999 & $0.4 \%$ (rate of daily devaluation: \\
$0.0133 \%$ )
\end{tabular}

D: Slovakia

Changes to koruna exchange regime

\begin{tabular}{|l|l|}
\hline 1 January 1991 & $\begin{array}{l}\text { Currency basket peg regime, Basket: 45.52\% DEM, 31.34\% USD, } \\
12.35 \% \text { ATS, 4.24\% GBP, 6.55\% CHF }\end{array}$ \\
\hline 2 January 1992 & $\begin{array}{l}\text { Change in Basket composition: 36.15\% DEM, 49.07\% USD, } \\
8.07 \% \text { ATS, 2.92\% FRF, 3.79\% CHF }\end{array}$ \\
\hline 8 February- 1993 & $\begin{array}{l}\text { Split of Czechoslovak currency - Slovak koruna, Basket: 36.16\% } \\
\text { DEM, 49.06\% USD, 8.07\% ATS, 2.92\% FRF, 3.79\% CHF, Band } \\
\pm 1.5 \%\end{array}$ \\
\hline 10 July 1993 & Devaluation 10\% \\
\hline 14 July 1994 & Basket changed: 60\% DEM, 40\% USD \\
\hline 1 January 1996 & Band $\pm 3 \%$ \\
\hline 31 July 1996 & Band $\pm 5 \%$ \\
\hline 1 January 1997 & Band $\pm 7 \%$ \\
\hline 2 October 1998 & Introduction of managed float \\
\hline 1 January 1999 & Reference currency EUR \\
\hline
\end{tabular}


Table 2.1

Basic Statistics: Daily returns of local currency with respect to the Euro

Fixed exchange rate regime

Floating exchange rate regime

\begin{tabular}{|c|c|c|c|c|c|c|c|c|}
\hline & $\begin{array}{l}\text { Czech } \\
\text { koruna }\end{array}$ & $\begin{array}{l}\text { Slovak } \\
\text { koruna }\end{array}$ & $\begin{array}{r}\text { Polish } \\
\text { zloty }\end{array}$ & $\begin{array}{r}\text { Hungarian } \\
\text { forint }\end{array}$ & $\begin{array}{r}\text { Czech } \\
\text { koruna }\end{array}$ & Slovak koruna & Polish zloty & $\begin{array}{r}\text { Hungarian } \\
\text { forint }\end{array}$ \\
\hline No. of Obs. & 1048 & 779 & 553 & 1136 & 1922 & 1594 & 1538 & 958 \\
\hline Mean & 1,15E-05 & $-3,53 E-05$ & 1,99E-04 & 2,64E-04 & $-1,04 \mathrm{E}-04$ & $-5,41 E-05$ & $-5,03 E-05$ & 1,34E-05 \\
\hline Std. Deviation & 0,0029 & 0,0034 & 0,0063 & 0,0024 & 0,0044 & 0,0030 & 0,0072 & 0,0057 \\
\hline Minimum & $-0,0130$ & $-0,0384$ & $-0,0327$ & $-0,0143$ & $-0,0269$ & $-0,0155$ & $-0,0582$ & $-0,0246$ \\
\hline Maximum & 0,0207 & 0,0157 & 0,0463 & 0,0164 & 0,0311 & 0,0248 & 0,0630 & 0,0691 \\
\hline Start & 5.01 .1993 & 07.07.1995 & 12.08.1996 & 01.08.1996 & 01.07.1997 & 01.12 .1998 & 02.02.1999 & 02.07.2001 \\
\hline End & 29.04.1997 & 28.09.1998 & 30.12.1998 & 27.04.2001 & 28.06.2005 & 28.06.2005 & 28.06.2005 & 28.06.2005 \\
\hline
\end{tabular}

Table 2.2

Basic Statistics: One-month interest rate on local currency

Fixed exchange rate regime

Floating exchange rate regime

\begin{tabular}{l|rrrr|rrr|r|}
\hline \hline & $\begin{array}{r}\text { Czech } \\
\text { koruna }\end{array}$ & $\begin{array}{r}\text { Slovak } \\
\text { koruna }\end{array}$ & $\begin{array}{r}\text { Polish } \\
\text { zloty }\end{array}$ & $\begin{array}{r}\text { Hungarian } \\
\text { forint }\end{array}$ & $\begin{array}{r}\text { Czech } \\
\text { koruna Slovak koruna }\end{array}$ & $\begin{array}{r}\text { Hungarian } \\
\text { Polish zloty }\end{array}$ \\
\hline No. of Obs. & 1048 & 779 & 553 & 1136 & 1922 & 1594 & 1538 & 958 \\
Mean & $11,1 \%$ & $16,7 \%$ & $22,4 \%$ & $16,7 \%$ & $6,1 \%$ & $8,0 \%$ & $11,3 \%$ & $9,6 \%$ \\
Std. Deviation & $2,3 \%$ & $8,1 \%$ & $2,6 \%$ & $4,1 \%$ & $4,5 \%$ & $3,6 \%$ & $5,2 \%$ & $1,9 \%$ \\
Minimum & $6,2 \%$ & $5,1 \%$ & $16,1 \%$ & $9,3 \%$ & $1,8 \%$ & $2,2 \%$ & $5,2 \%$ & $4,2 \%$ \\
Maximum & $20,0 \%$ & $62,5 \%$ & $27,3 \%$ & $23,9 \%$ & $22,7 \%$ & $30,0 \%$ & $21,8 \%$ & $15,2 \%$ \\
\hline Start & 05.01 .1993 & 07.07 .1995 & 12.08 .1996 & 01.08 .1996 & 01.07 .1997 & 01.12 .1998 & 02.02 .1999 & 02.07 .2001 \\
End & 29.04 .1997 & 28.09 .1998 & 30.12 .1998 & 27.04 .2001 & 28.06 .2005 & 28.06 .2005 & 28.06 .2005 & 28.06 .2005 \\
\hline \hline
\end{tabular}


Table 3

Shocks to Exchange Rate Returns

\begin{tabular}{|c|c|c|c|c|c|}
\hline & \multirow{2}{*}{$\begin{array}{c}\text { Total number } \\
\text { of } \\
\text { observations }\end{array}$} & \multirow{2}{*}{$\begin{array}{l}\text { Criterion } \\
\text { for shock }\end{array}$} & \multicolumn{3}{|c|}{ Exchange rates } \\
\hline & & & $\begin{array}{c}\text { Depreciative } \\
\text { shocks }\end{array}$ & $\begin{array}{c}\text { Apreciative } \\
\text { shocks }\end{array}$ & Total \\
\hline \multicolumn{6}{|c|}{ Fixed exchange rate regime } \\
\hline Czech koruna & 1048 & $>5 * \mathrm{SD}$ & 4 & 0 & 4 \\
\hline Slovak koruna & 779 & $>5 * \mathrm{SD}$ & 2 & 1 & 3 \\
\hline Polish zloty & 553 & $>5 * \mathrm{SD}$ & 3 & 2 & 5 \\
\hline Hungarian forint & 1136 & $>5 * \mathrm{SD}$ & 3 & 1 & 4 \\
\hline \multicolumn{6}{|c|}{ Floating exchange rate regime } \\
\hline Czech koruna & 1922 & $>5 * \mathrm{SD}$ & 2 & 4 & 6 \\
\hline Slovak koruna & 1593 & $>5 * \mathrm{SD}$ & 3 & 1 & 4 \\
\hline Polish zloty & 1535 & $>5 * \mathrm{SD}$ & 2 & 2 & 4 \\
\hline Hungarian forint & 958 & $>2 * \mathrm{SD}$ & 19 & 14 & 33 \\
\hline
\end{tabular}

Note: SD means standard deviation 
Table 4

Results of the TGARCH-M Volatility Estimation: Czech koruna

\begin{tabular}{|c|c|c|c|c|c|c|}
\hline & \multicolumn{3}{|c|}{ Fixed regime } & \multicolumn{3}{|c|}{ Floating regime } \\
\hline & Coefficient & Std. Error & Prob. & Coefficient & Std. Error & Prob. \\
\hline$\overline{a_{0}}$ & $-0,0042$ & 0,0021 & 0,0448 & $-0,0002$ & 0,0001 & 0,0041 \\
\hline$a_{1}$ & - & & & - & & \\
\hline$a_{2}$ & - & & & - & & \\
\hline$a_{3}$ & - & & & - & & \\
\hline$b$ & $-0,0003$ & 0,0002 & 0,0458 & - & & \\
\hline$\lambda$ & 0,0167 & 0,0021 & 0,0000 & 0,0237 & 0,0014 & 0,0000 \\
\hline$\omega$ & 0,0000 & 0,0000 & 0,1192 & 0,0000 & 0,0000 & 0,0011 \\
\hline$\alpha_{1}$ & 0,0612 & 0,0190 & 0,0013 & 0,0672 & 0,0197 & 0,0007 \\
\hline$\alpha_{2}$ & - & & & - & & \\
\hline$\beta$ & 0,9307 & 0,0224 & 0,0000 & 0,8910 & 0,0224 & 0,0000 \\
\hline$\xi$ & $-0,0274$ & 0,0200 & 0,1697 & 0,0107 & 0,0229 & 0,6407 \\
\hline$\delta_{1}$ & 0,0002 & 0,0001 & 0,0986 & 0,0009 & 0,0003 & 0,0064 \\
\hline GED parameter & 1,3672 & 0,0734 & 0,0000 & 1,2490 & 0,0487 & 0,0000 \\
\hline Num. of obs & & 1048 & & & 1922 & \\
\hline Adjusted $\mathrm{R}^{2} / \mathrm{DW}$ & & $129 / 1.961$ & & & 107/1.982 & \\
\hline Log Likelihood & & 1776,383 & & & 044,795 & \\
\hline $\mathrm{AIC} / \mathrm{SIC}$ & & 098/-9.056 & & & $363 /-8.340$ & \\
\hline $\operatorname{sum}(\alpha+\beta)$ & & 0.9919 & & & 0.9582 & \\
\hline
\end{tabular}

Note: DW means Durbin-Watson statistics, AIC and SIC stand for Akaike and Schwarz-Bayesian information criteria respectively

Table 5

Results of the TGARCH-M Volatility Estimation: Slovak koruna

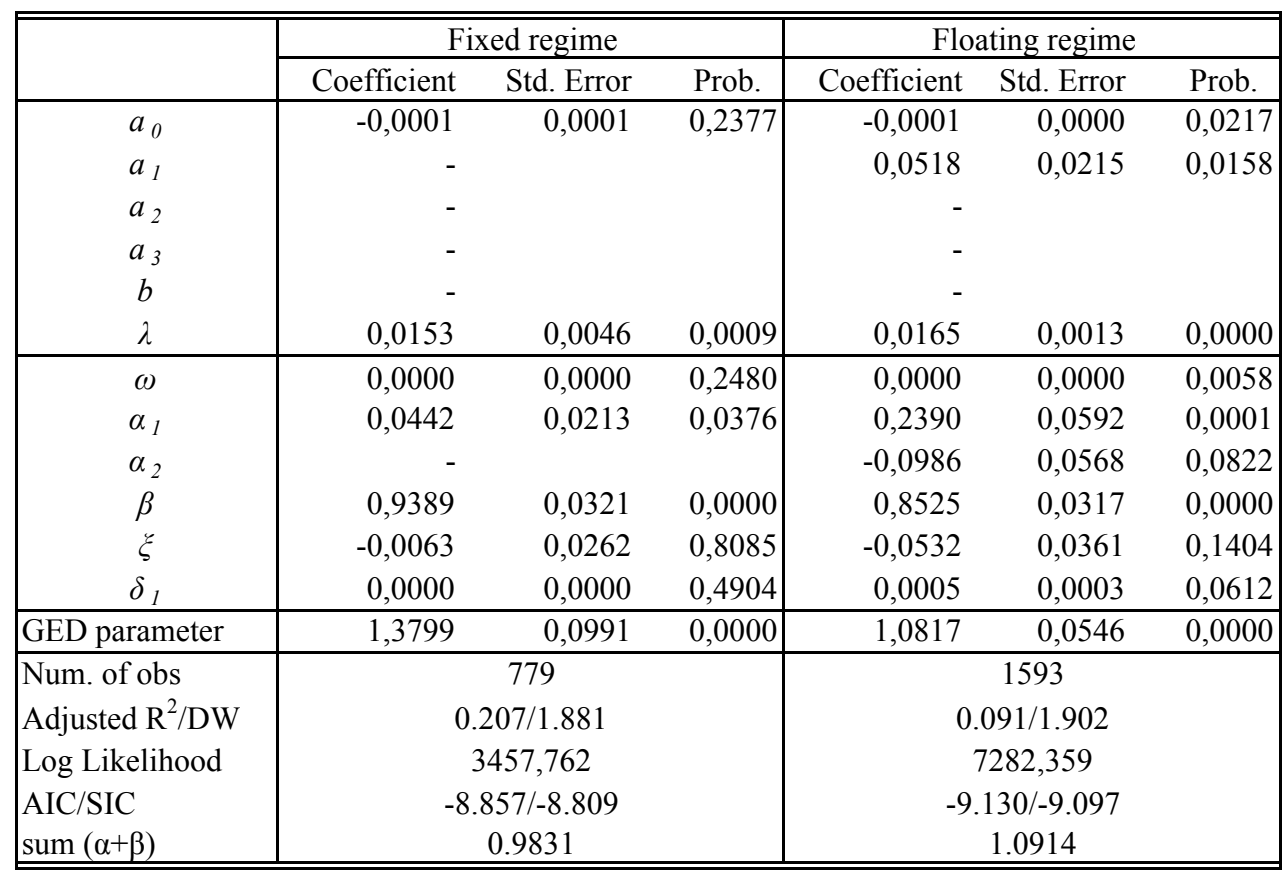

Note: DW means Durbin-Watson statistics, AIC and SIC stand for Akaike and Schwarz-Bayesian information criteria respectively 
Table 6

Results of the TGARCH-M Volatility Estimation: Hungarian forint

\begin{tabular}{|c|c|c|c|c|c|c|}
\hline & \multicolumn{3}{|c|}{ Fixed regime } & \multicolumn{3}{|c|}{ Floating regime } \\
\hline & Coefficient & Std. Error & Prob. & Coefficient & Std. Error & Prob. \\
\hline$a_{0}$ & 0,0001 & 0,0000 & 0,0000 & $-0,0149$ & 0,0044 & 0,0007 \\
\hline$a_{1}$ & \multicolumn{3}{|l|}{ - } & \multicolumn{3}{|l|}{-} \\
\hline$a_{2}$ & \multicolumn{3}{|l|}{ - } & \multicolumn{3}{|l|}{-} \\
\hline$a_{3}$ & \multicolumn{3}{|l|}{-} & \multicolumn{3}{|l|}{ - } \\
\hline$b$ & - & & & $-0,0013$ & 0,0004 & 0,0008 \\
\hline$\lambda$ & 0,0143 & 0,0014 & 0,0000 & 0,0118 & 0,0005 & 0,0000 \\
\hline$\omega$ & 0,0000 & 0,0000 & 0,0062 & 0,0000 & 0,0000 & 0,0085 \\
\hline$\alpha_{1}$ & 0,3050 & 0,0541 & 0,0000 & 0,1060 & 0,0301 & 0,0004 \\
\hline$\alpha_{2}$ & \multicolumn{3}{|l|}{-} & \multicolumn{3}{|l|}{-} \\
\hline$\beta$ & 0,7981 & 0,0248 & 0,0000 & 0,8555 & 0,0408 & 0,0000 \\
\hline$\xi$ & $-0,2089$ & 0,0593 & 0,0004 & $-0,1345$ & 0,0375 & 0,0003 \\
\hline$\delta_{1}$ & 0,0001 & 0,0000 & 0,0036 & 0,0009 & 0,0004 & 0,0410 \\
\hline GED parameter & 1,1381 & 0,0593 & 0,0000 & 1,3727 & 0,0996 & 0,0000 \\
\hline Num. of obs & \multicolumn{3}{|c|}{1136} & \multicolumn{3}{|c|}{958} \\
\hline Adjusted $\mathrm{R}^{2} / \mathrm{DW}$ & \multicolumn{3}{|c|}{$0.128 / 1.915$} & \multicolumn{3}{|c|}{$0.616 / 1.923$} \\
\hline Log Likelihood & \multicolumn{3}{|c|}{5690,182} & \multicolumn{3}{|c|}{4094,326} \\
\hline AIC/SIC & \multirow{2}{*}{\multicolumn{3}{|c|}{$\begin{array}{c}-10.004 /-9.968 \\
1.1031\end{array}$}} & \multirow{2}{*}{\multicolumn{3}{|c|}{$\begin{array}{c}-8.529 /-8.483 \\
0.9615\end{array}$}} \\
\hline $\operatorname{sum}(\alpha+\beta)$ & & & & & & \\
\hline
\end{tabular}

Note: DW means Durbin-Watson statistics, AIC and SIC stand for Akaike and Schwarz-Bayesian information criteria respectively

Table 7

Results of the TGARCH-M Volatility Estimation: Polish zloty

\begin{tabular}{|c|c|c|c|c|c|c|}
\hline & \multicolumn{3}{|c|}{ Fixed regime } & \multicolumn{3}{|c|}{ Floating regime } \\
\hline & Coefficient & Std. Error & Prob. & Coefficient & Std. Error & Prob. \\
\hline$a_{0}$ & $-0,0058$ & 0,0032 & 0,0752 & $-0,0002$ & 0,0002 & 0,1344 \\
\hline$a_{1}$ & - & & & $-0,0622$ & 0,0239 & 0,0093 \\
\hline$a_{2}$ & - & & & $-0,0806$ & 0,0251 & 0,0013 \\
\hline$a_{3}$ & - & & & $-0,0585$ & 0,0242 & 0,0158 \\
\hline$b$ & $-0,0005$ & 0,0003 & 0,0795 & - & & \\
\hline$\lambda$ & 0,0232 & 0,0018 & 0,0000 & 0,0355 & 0,0017 & 0,0000 \\
\hline$\omega$ & 0,0000 & 0,0000 & 0,9713 & 0,0000 & 0,0000 & 0,0004 \\
\hline$\alpha_{1}$ & 0,1260 & 0,0568 & 0,0264 & 0,1535 & 0,0379 & 0,0001 \\
\hline$\alpha_{2}$ & 0,1904 & 0,0563 & 0,0007 & - & & \\
\hline$\beta_{1}$ & $-0,1499$ & 0,0721 & 0,0376 & 0,7760 & 0,0549 & 0,0000 \\
\hline$\beta_{2}$ & 0,6560 & 0,0756 & 0,0000 & - & & \\
\hline$\xi$ & 0,0134 & 0,0666 & 0,8408 & $-0,1611$ & 0,0404 & 0,0001 \\
\hline$\delta_{1}$ & 0,0016 & 0,0008 & 0,0599 & 0,0015 & 0,0007 & 0,0339 \\
\hline GED parameter & 1,0333 & 0,0775 & 0,0000 & 1,4778 & 0,0732 & 0,0000 \\
\hline Num. of obs & & 553 & & & 1535 & \\
\hline Adjusted $\mathrm{R}^{2} / \mathrm{DW}$ & & $273 / 1.972$ & & & $134 / 1.957$ & \\
\hline Log Likelihood & & 227,365 & & & 592,681 & \\
\hline AIC/SIC & & $016 /-7.930$ & & & $273 /-7.234$ & \\
\hline $\operatorname{sum}(\alpha+\beta)$ & & 0.6321 & & & 0.9295 & \\
\hline
\end{tabular}

Note: DW means Durbin-Watson statistics, AIC and SIC stand for Akaike and Schwarz-Bayesian information criteria respectively 
Table 8

Correlations for Exchange Rate (TARCH-M) Volatility

\begin{tabular}{|l|cccc|}
\hline \hline & $\begin{array}{l}\text { Czech } \\
\text { koruna }\end{array}$ & $\begin{array}{l}\text { Slovak } \\
\text { koruna }\end{array}$ & $\begin{array}{l}\text { Polish } \\
\text { zloty }\end{array}$ & $\begin{array}{l}\text { Hungarian } \\
\text { forint }\end{array}$ \\
\hline \multicolumn{5}{|c|}{ Fixed exchange rate regime } \\
\hline Czech koruna & 1 & 1 & & \\
Slovak koruna & 0,117 & 0,432 & 1 & \\
Polish zloty & $-0,247$ & 0,030 & 0,488 & 1 \\
Hungarian forint & $-0,313$ & \multicolumn{5}{c}{} \\
\hline \multicolumn{5}{|c|}{ Floating exchange rate regime } \\
\hline Czech koruna & 1 & 1 & 1 \\
Slovak koruna & 0,246 & 0,199 & 1 \\
Polish zloty & 0,096 & $-0,019$ & $-0,045$ & 1 \\
Hungarian forint & 0,012 &
\end{tabular}

Note: Correlation coefficients are calculated over the common sample for all currencies under specific exchange rate regime. The length of the sample is 160 and 958 observations for fixed and floating regimes, respectively. 
Figure 1

Conditional Variance: Czech koruna

Panel A: Czech koruna - Fixed regime

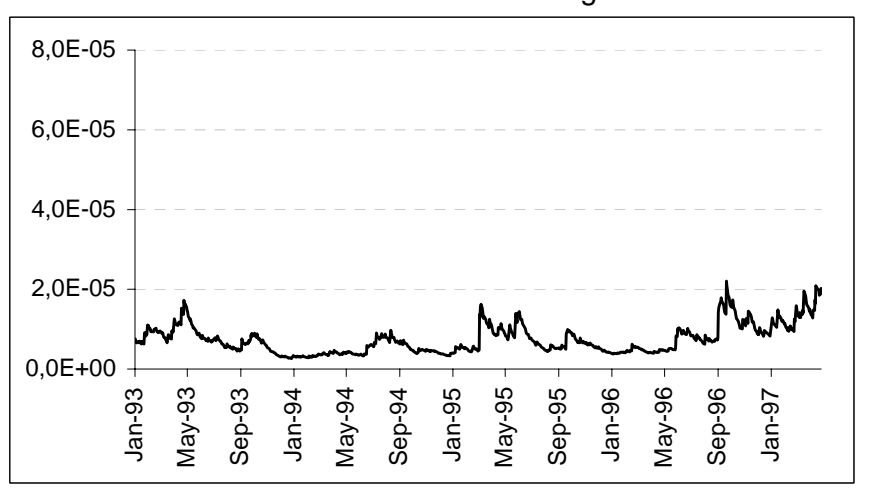

Panel B: Czech koruna - Floating regime

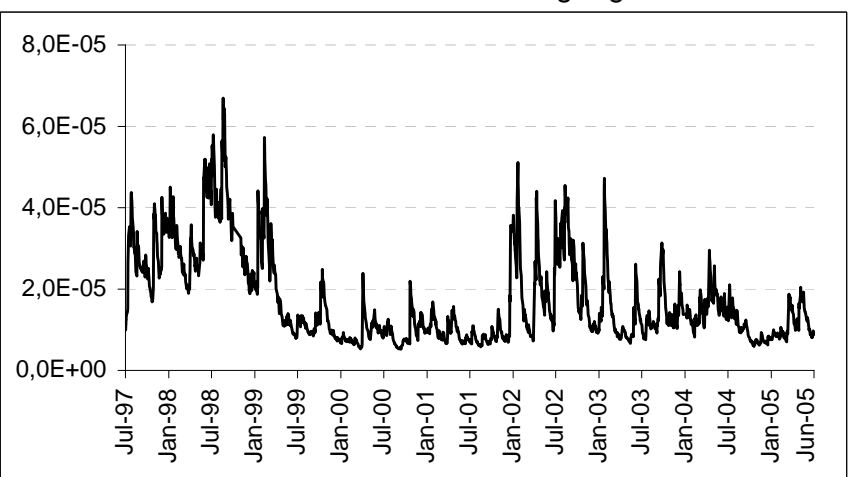

Figure 2

Conditional Variance: Slovak koruna

Panel A: Slovak koruna - Fixed regime

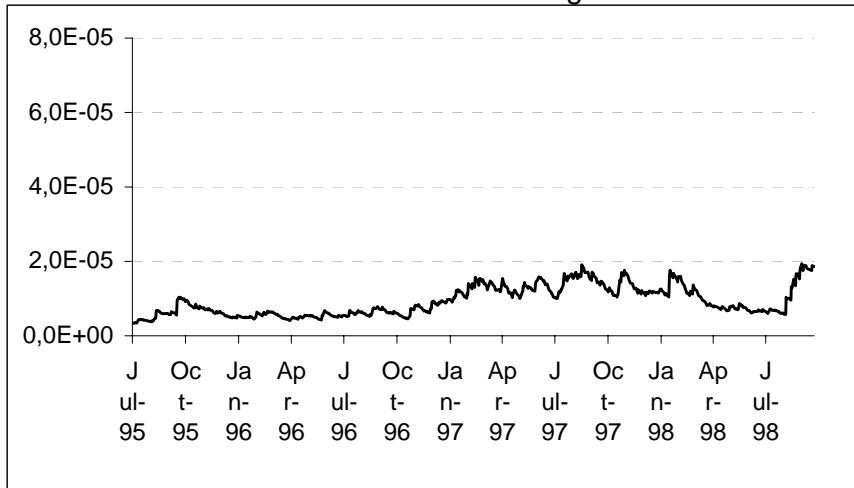

Panel B: Slovak koruna - Floating regime

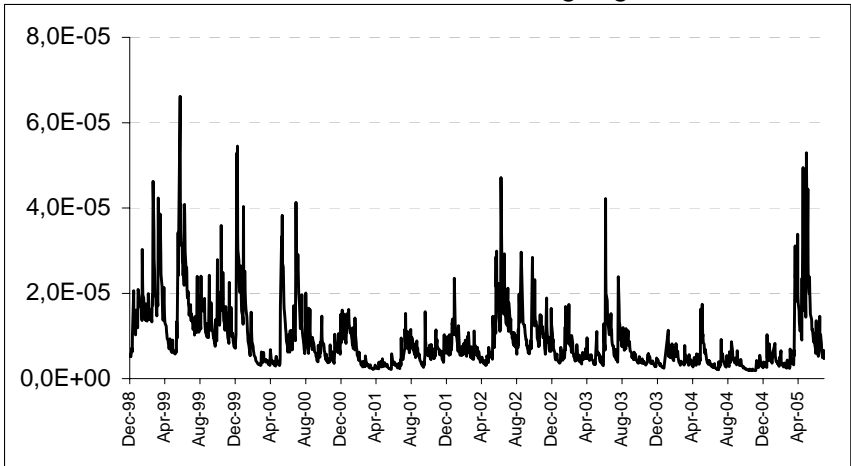

Figure 3

Conditional Variance: Polish zloty

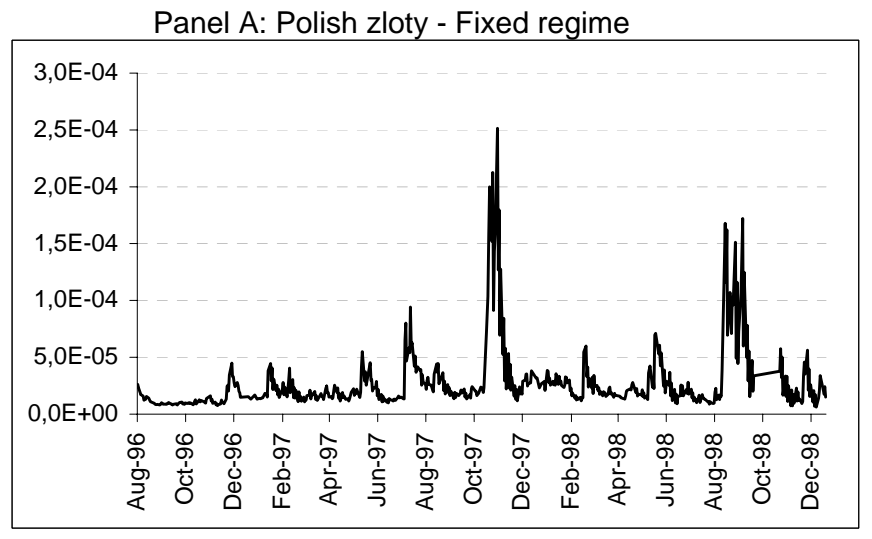

Panel B: Polish zloty - Floating regime

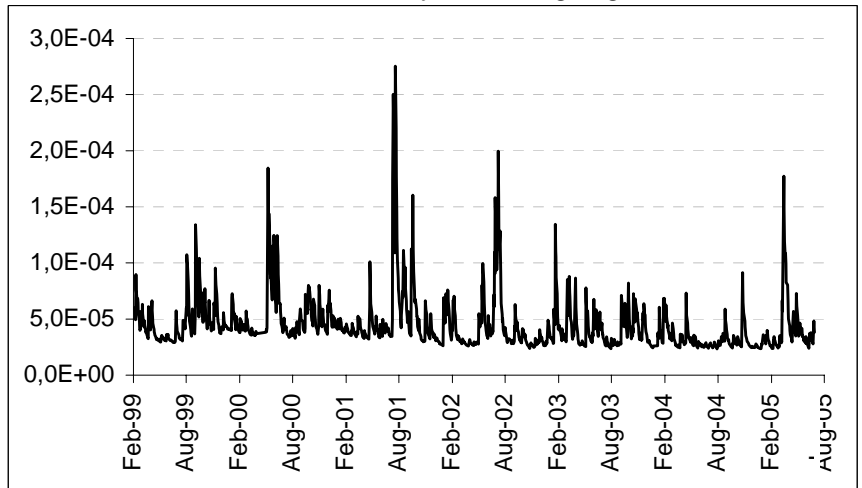

Figure 4

Conditional Variance: Hungarian forint

Panel A: Hungarian forint - Fixed regime

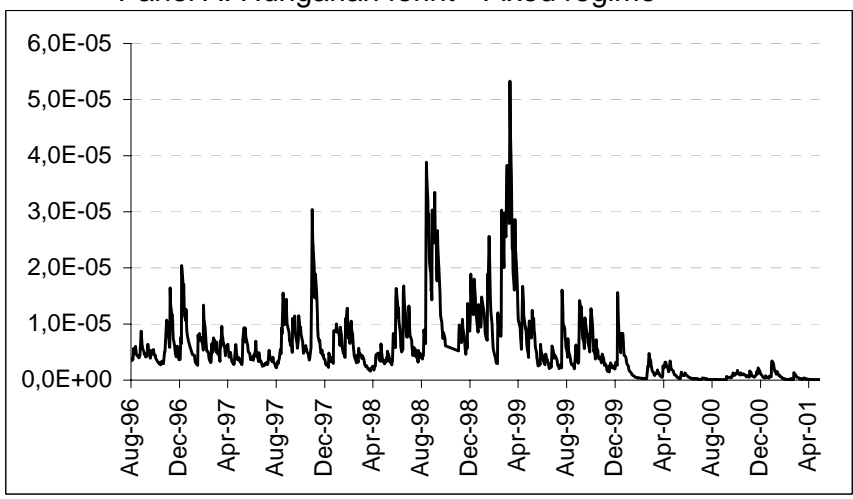

Panel B: Hungarian forint - Floating regime

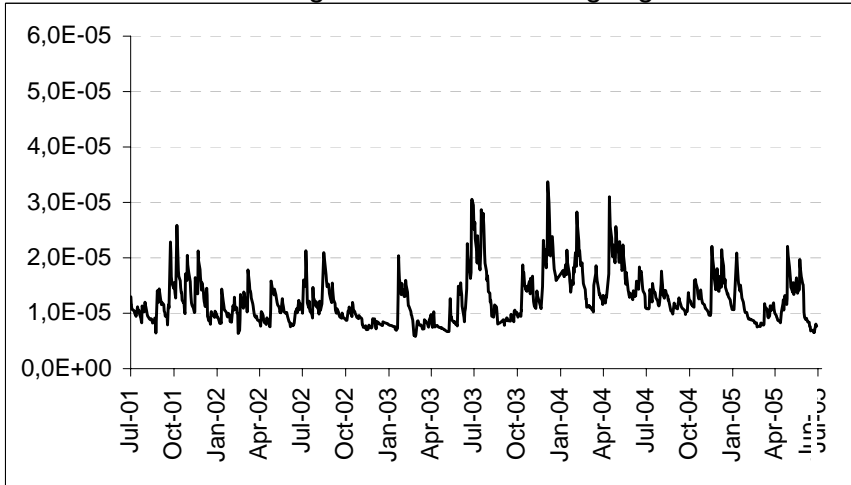

